\title{
QUARTERLY OUTLOOK ON \\ MONETARY, BANKING, AND PAYMENT SYSTEM IN INDONESIA: QUARTER I, 2017
}

\author{
Bambang Pramono, Syachman Perdymer, Handri Adiwilaga, \\ Nurkholisoh Ibnu Aman, Rio Khasananda, Saraswati, Illinia A. Riyadi'
}

\begin{abstract}
Globally, the economy continues to recover. The economic growth in AS increases supported by solid consumption and increase on non-residential investment, as well as the economy of Tiongkok, supported by private investment and better export performance. European economy also better off with stronger consumption and export, and the reduction of geopolitical risk post the presidential election in France. The economy in Japan also increases supported by stronger domestic and export demand. This global trend supports the growth in Indonesia that rises to the level of 5,01\% (yoy), with the pillars of export performance, better global demand and commodity prices, as well as higher government expenditure particularly on investment - and the household consumption. Spatially, the national growth was mainly from Java and Kalimantan due to their better export performance. Inflation increases slightly particularly related to price regulation implemented in early 2017. Spatially, inflation occurs in most area except Sumatera who recorded deflation. The balance of payment recorded a surplus arisen from financial and capital surplus of 7.9 milliard dolar AS. However, the current account recorded deficit due to the deficit of oil trade balance and primary income. The reserve increases to 121.8 miliar dolar AS, accompanied with stronger Rupiah with lower volatility relative to peer countries. Following the monetary ease on previous Quarter IV, 2016, the monetary transmission is better yet not optimal due to the prudent practice of the bank on allocating credit. The interest rate decreases reflected on daily PUAB O/N reduction by 7 point to $4.23 \%$. The deposit rate also decreases as well as the lending rate with larger decrease. Looking forward, the growth in 2017 will be higher than 2016 on the range of $5.0-5.4 \%$, while inflation will be around the target of $4 \pm 1 \%$. We need to anticipate the impact of Fed Fund Rate increase, the lower of FED balance, and the trade and fiscal US policy, as well as the geopolitical dynamics across regions particularly in Korean Bay. Bank Indonesia will keep strengthening his policy mix and macroprudential, and his coordination with the government to ensure the inflation control, greater stimulus for growth, and the implementation of structural reform run on the right track, and hence preserve the sustainable economic development.
\end{abstract}

Keywords: Macroeconomy, monetary, economic outlook.

JEL Classification: C53, E66, F01, F41

1 Authors are researcher on Monetary and Economic Policy Department (DKEM). Bambang Pramono (bpramono@bi.go.id); Syachman Perdymer (syachman@bi.go.id); Handri Adiwilaga (adiwilaga@bi.go.id); Nurkholisoh Ibnu Aman (nurkholisoh@bi.go.id); Rio Khasananda (rio_k@bi.go.id); Saraswati (saraswati@bi.go.id); Illinia Ayudhia Riyadi (illinia_ar@bi.go.id). 


\section{PERKEMBANGAN GLOBAL}

Pertumbuhan ekonomi dunia diperkirakan membaik, meskipun beberapa risiko tetap perlu dicermati. Peningkatan prospek ekonomi dunia ditopang oleh meningkatnya pertumbuhan ekonomi di AS, Tiongkok, Eropa dan Jepang. Perekonomian di AS didukung oleh konsumsi yang solid serta peningkatan investasi nonresidensial. Di Tiongkok, perekonomian tumbuh lebih baik dengan meningkatnya kegiatan investasi swasta dan perbaikan ekspor. Di Eropa, pertumbuhan ekonomi didorong oleh meningkatnya kinerja sektor manufaktur sejalan dengan perbaikan konsumsi dan ekspor, serta telah menurunnya risiko geopolitik pasca Pemilihan Presiden di Perancis.

Di Jepang, kenaikan permintaan domestik dan ekspor telah mendorong perbaikan pertumbuhan ekonomi di negara tersebut. Sejalan dengan perbaikan pertumbuhan ekonomi dunia tersebut, volume perdagangan dunia dan harga komoditas non migas mengalami peningkatan. Ke depan, sejumlah risiko terhadap perekonomian global tetap perlu diwaspadai, antara lain kenaikan Fed Fund Rate, kebijakan fiskal dan perdagangan serta penurunan besaran neraca bank sentral AS, dan perkembangan geopolitik di beberapa kawasan, khususnya di Semenanjung Korea.

Meningkatnya kinerja perekonomian di AS didukung oleh konsumsi yang solid serta peningkatan investasi nonresidensial. Konsumsi AS yang solid tercermin dari pertumbuhan konsumsi pada triwulan I 2017 yang masih cukup kuat yaitu sebesar 2,8\% (yoy) (Grafik 1). Pertumbuhan konsumsi melanjutkan kinerja positif selama setahun terakhir yang tumbuh di kisaran 2,7\%-3,1\% (yoy). Pertumbuhan konsumsi yang solid tersebut didukung oleh kondisi ketenagakerjaan yang membaik, tercermin dari menurunnya tingkat pengangguran dan meningkatnya pertumbuhan upah.

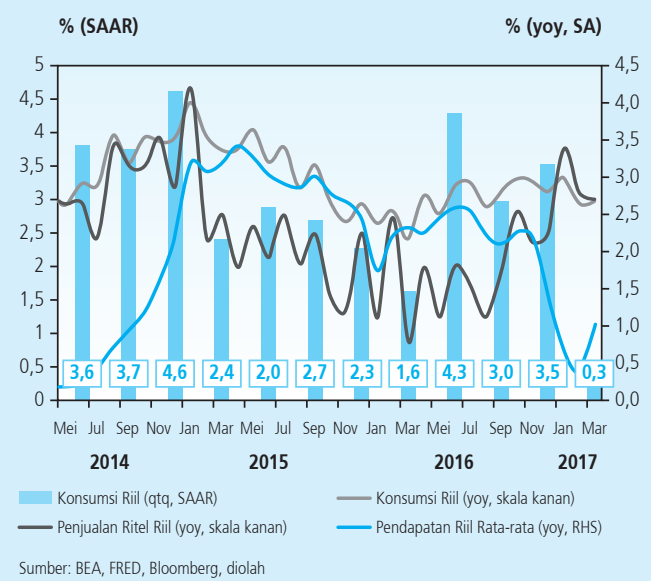

Grafik 1.

Konsumsi, Penjualan Ritel, dan Pendapatan

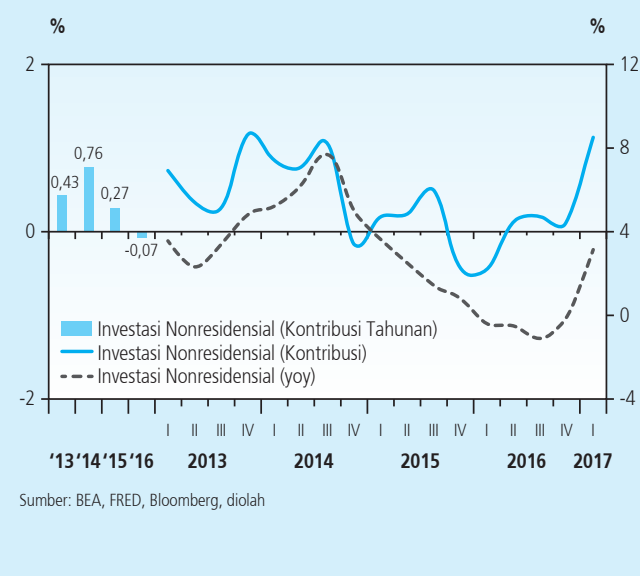

Grafik 2. Investasi Nonresidensial AS 
Selain itu, investasi nonresidensial AS juga meningkat, antara lain tercermin dari pertumbuhan positif belanja konstruksi nonresidensial (7,5\%, yoy), dan pertumbuhan pengiriman barang modal yang cukup solid (2,5\%) dan melanjutkan tren positif (Grafik 2). Investasi nonresidensial diperkirakan tetap kuat mendukung investasi pada 2017, terutama dari sektor energi seiring dengan harga minyak yang diperkirakan masih tinggi.

Perekonomian Tiongkok tumbuh lebih baik dengan meningkatnya investasi swasta dan perbaikan ekspor. Perekonomian Tiongkok pada triwulan I 2017 tumbuh sebesar 6,9\% (yoy), lebih baik dibanding ekspektasi dan pertumbuhan pada triwulan sebelumnya yang tercatat 6,8\% (yoy). Pada triwulan I 2017, kinerja investasi membaik, didorong oleh investasi swasta yang berkontribusi sebesar 70\% terhadap investasi agregat. Investasi swasta melanjutkan pemulihan pada triwulan I 2017 dengan pertumbuhan sebesar 7,7\% (yoy), mengimbangi perlambatan investasi Pemerintah (Grafik 3).

Meningkatnya pertumbuhan ekonomi Tiongkok juga didukung oleh membaiknya kinerja sektor eksternal, tercermin dari ekspor dan impor triwulan I 2017 yang tumbuh pesat sejalan dengan pulihnya permintaan global dan reflasi harga komoditas (Grafik 4). Pada triwulan I 2017, pertumbuhan ekspor Tiongkok tercatat sebesar 22,3\% (yoy), lebih tinggi dibandingkan pertumbuhan pada triwulan IV 2016 yang hanya sebesar 0,6\% (yoy). Pertumbuhan ekspor tersebut sejalan dengan pulihnya permintaan global. Ke depan, pulihnya permintaan global diperkirakan mendukung kinerja perdagangan Tiongkok.

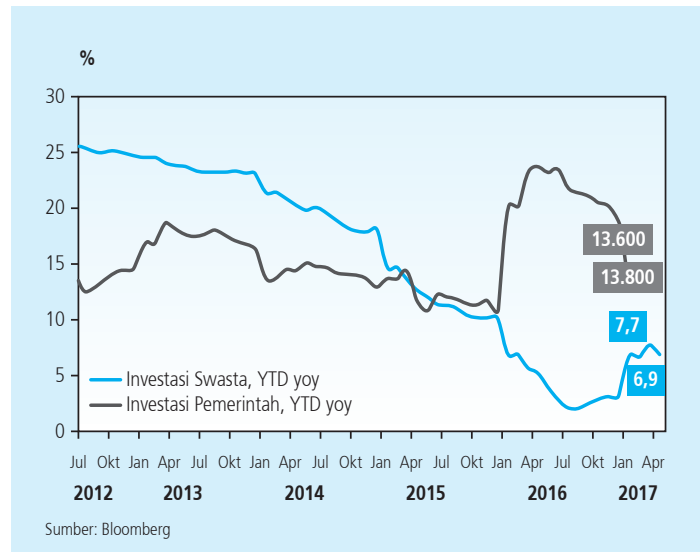

Grafik 3. Perkembangan Investasi Pemerintah dan Swasta Tiongkok

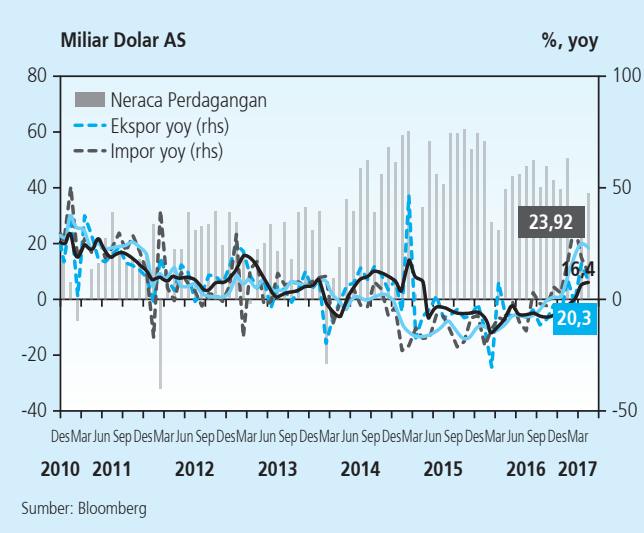

Grafik 4.

Perkembangan Kinerja Perdagangan Tiongkok

Sementara itu, pertumbuhan ekonomi Eropa didukung oleh meningkatnya kinerja sektor manufaktur sejalan dengan perbaikan konsumsi dan ekspor, serta telah menurunnya risiko geopolitik pasca Pemilihan Presiden di Perancis. Sektor industri dan manufaktur Eropa pada triwulan I 2017 menunjukkan optimisme, tercermin dari perkembangan indeks PMI manufaktur 
yang masih melanjutkan periode ekspansinya dan mencapai level tertinggi sejak 2011 pada April 2017, yakni sebesar 56,8 (Grafik 5). Sejalan dengan hal tersebut, aktivitas konsumsi juga meningkat, didukung oleh tren kenaikan Indeks Keyakinan Ekonomi (IKE) (Grafik 6). Selain itu, kinerja ekspor juga terus meningkat pada triwulan I 2017 sehingga mendorong neraca perdagangan Eropa terus mengalami surplus (Grafik 7). Ekspor tumbuh sebesar 8,3\% (yoy) pada triwulan I 2017 dan mencapai nilai 500,6 miliar euro.

Peningkatan ekspor terjadi sejak Oktober 2016, ditopang oleh naiknya permintaan global dan Euro yang mengalami depresiasi terhadap dolar AS sampai dengan akhir tahun 2016. Selain itu, risiko geopolitik di Eropa terus menurun seiring dengan kekalahan kelompok populis pada Pemilu di Perancis, setelah sebelumnya kelompok populis juga mengalami kekalahan dalam Pemilu di Belanda. Hal ini tercermin dari meningkatnya rata-rata Sentix Investor Confidence dan rata-rata Zew Survey Expectation (Grafik 8).

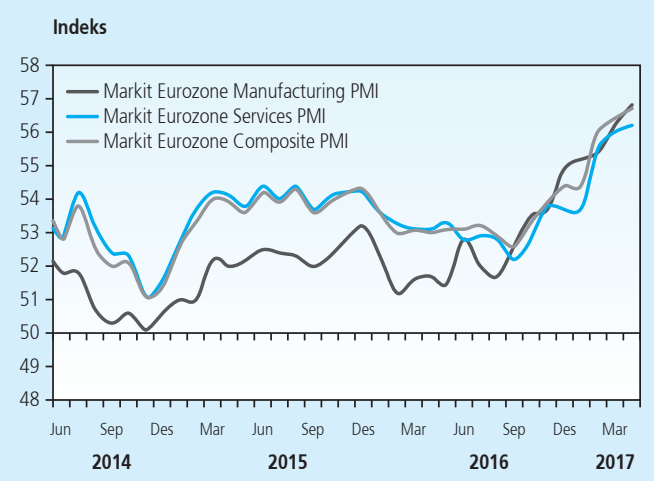

Sumber: Bloomberg, diolah

Grafik 5.

PMI Manufaktur Eropa

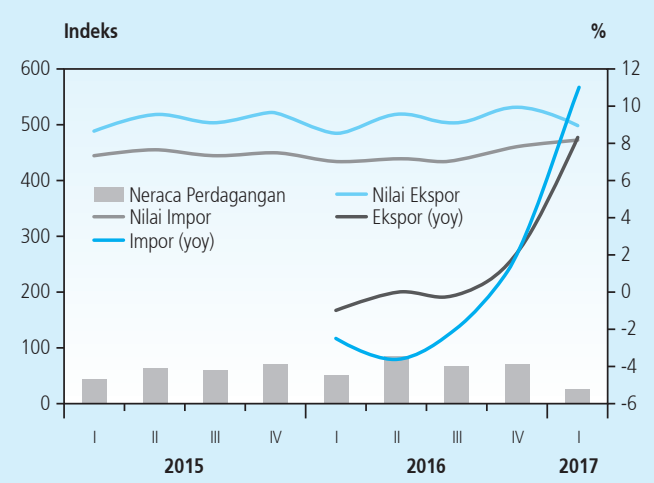

Sumber: Bloomberg, diolah

Grafik 7.

Kinerja Perdagangan Eropa



Sumber: Bloomberg, diolah

Grafik 6.

Perkembangan Indeks Keyakinan Ekonomi Eropa

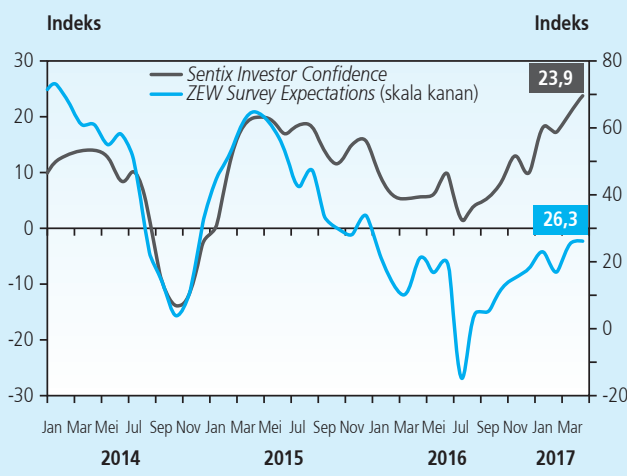

Sumber: Bloomberg, diolah

Grafik 8.

Tingkat Keyakinan Investor di Kawasan Euro 
Perekonomian Jepang ditopang oleh permintaan domestik dan ekspor mengalami pertumbuhan meningkat. Kenaikan permintaan domestik di Jepang mendorong peningkatan indeks Industrial Production (IP) Jepang (Grafik 9). Rata-rata pertumbuhan indeks IP pada triwulan I 2017 sebesar 4,0\% (yoy), lebih tinggi dibandingkan triwulan I 2016 yang justru mengalami kontraksi sebesar 1,4\% (yoy) dan triwulan IV 2016 yang tumbuh lebih lambat sebesar 2,1\% (yoy). Selain itu, ekspor juga melanjutkan perbaikan pada triwulan I 2017, tercermin dari pertumbuhannya yang tercatat sebesar 8,2\% (yoy), lebih tinggi dibandingkan pertumbuhan pada triwulan IV 2016 sebesar 1,8\% (Grafik 10). Meningkatnya ekspor Jepang dipengaruhi oleh pelemahan yen terhadap mata uang peers (sejak November 2016 s.d. Februari 2017), meskipun dalam beberapa waktu terakhir terdapat kecenderungan penguatan.

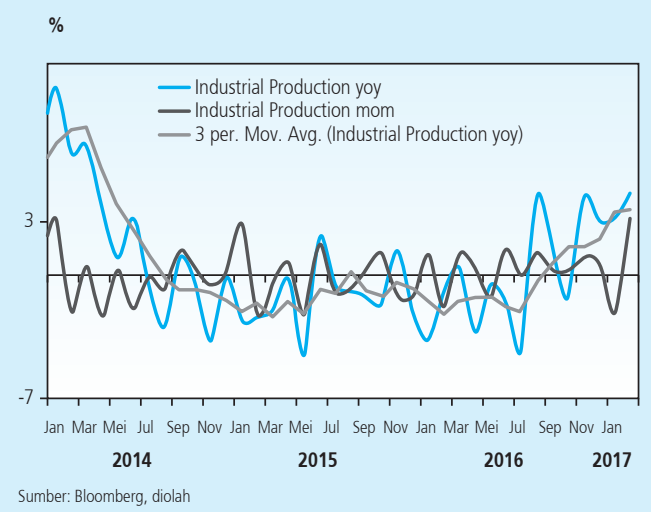

Grafik 9. Industrial Production Jepang

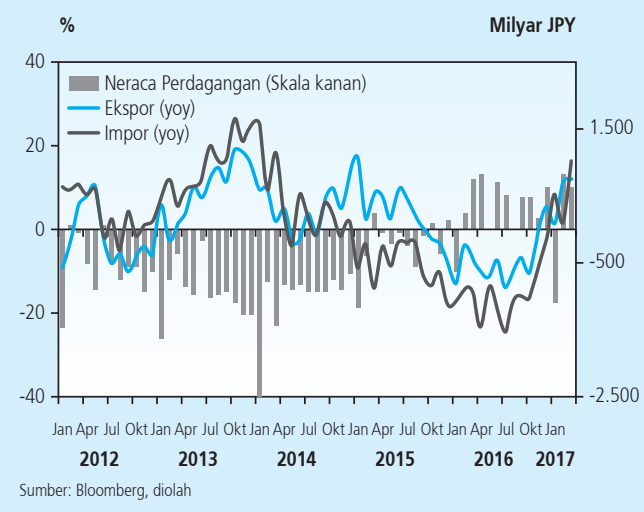

Grafik 10.

Ekspor, Impor, dan Neraca Perdagangan Jepang

Sejalan dengan perbaikan pertumbuhan ekonomi dunia tersebut, volume perdagangan dunia dan harga komoditas non migas diprakirakan lebih tinggi dari prakiraan sebelumnya. Volume perdagangan dunia pada 2017 dan 2018 diperkirakan lebih tinggi seiring dengan koreksi ke atas realisasi pertumbuhan volume perdagangan dunia tahun 2016, didukung membaiknya perdagangan Tiongkok dan PDB dunia. Negara emerging markets, terutama Tiongkok sebagai negara dengan volume perdagangan terbesar di dunia, menjadi sumber utama perbaikan volume perdagangan dunia (Grafik 11). 


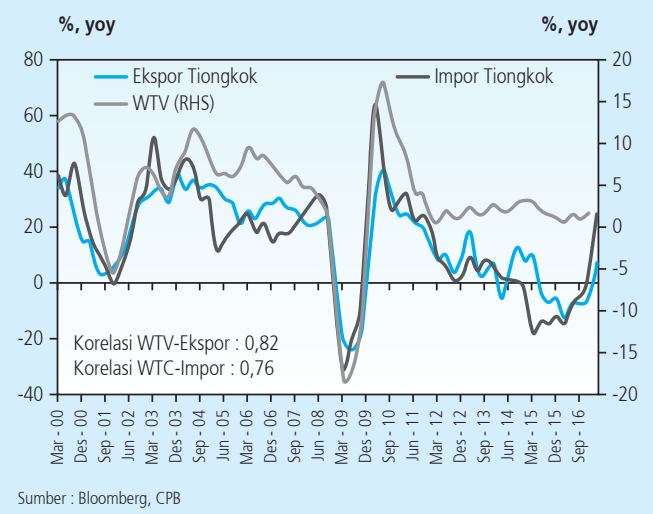

Grafik 11. Volume Perdagangan Dunia dan Ekspor Impor Tiongkok

\section{DINAMIKA MAKROEKONOMI INDONESIA}

\subsection{Pertumbuhan Ekonomi}

Perekonomian Indonesia pada triwulan I 2017 tumbuh membaik sebesar 5,01\% (yoy), lebih tinggi dibandingkan triwulan sebelumnya sebesar 4,94\% (yoy). Pertumbuhan yang tinggi tercatat pada ekspor dan belanja pemerintah (Tabel 1). Perbaikan kinerja ekspor terutama dipengaruhi oleh membaiknya harga komoditas global, seperti batubara dan karet, serta meningkatnya pertumbuhan ekonomi dunia. Sementara itu, meningkatnya konsumsi pemerintah didorong oleh belanja barang dan modal sehingga dapat memperbaiki kinerja investasi terutama investasi bangunan.

\begin{tabular}{|c|c|c|c|c|c|c|c|c|c|c|c|}
\hline \multicolumn{12}{|c|}{$\begin{array}{c}\text { Tabel } 1 . \\
\text { Pertumbuhan Ekonomi Sisi Pengeluaran }\end{array}$} \\
\hline \multirow{3}{*}{ Komponen } & & & & & & & & & & & Persen, yoy \\
\hline & \multicolumn{4}{|c|}{2015} & \multirow{2}{*}{2015} & \multicolumn{4}{|c|}{2016} & \multirow{2}{*}{2016} & \multirow{2}{*}{$\begin{array}{c}2017 \\
\mathrm{I}\end{array}$} \\
\hline & 1 & II & III & IV & & I & ॥ & III & IV & & \\
\hline Konsumsi Rumah Tangga & 5,01 & 4,97 & 4,95 & 4,93 & 4,96 & 4,97 & 5,07 & 5,01 & 4,99 & 5,01 & 4,93 \\
\hline Konsumsi LNPRT & $-8,06$ & $-7,98$ & 6,57 & 8,33 & $-0,62$ & 6,40 & 6,71 & 6,64 & 6,72 & 6,62 & 8,02 \\
\hline Konsumsi Pemerintah & 2,91 & 2,61 & 7,09 & 7,12 & 5,32 & 3,43 & 6,23 & $-2,95$ & $-4,05$ & $-0,15$ & 2,71 \\
\hline Investasi & 4,60 & 4,01 & 4,93 & 6,43 & 5,01 & 4,67 & 4,18 & 4,24 & 4,80 & 4,48 & 4,81 \\
\hline Investasi Bangunan & 5,71 & 4,72 & 6,11 & 7,78 & 6,11 & 6,78 & 5,07 & 4,96 & 4,07 & 5,18 & 5,90 \\
\hline Investasi NonBangunan & 1,62 & 2,05 & 1,65 & 2,47 & 1,95 & $-1,20$ & 1,70 & 2,16 & 7,07 & 2,45 & 1,55 \\
\hline Ekspor Barang dan Jasa & $-0,68$ & $-0,26$ & $-0,95$ & $-6,38$ & $-2,12$ & $-3,29$ & $-2,18$ & $-5,65$ & 4,24 & $-1,74$ & 8,04 \\
\hline Impor Barang dan Jasa & $-2,63$ & $-7,37$ & $-6,65$ & $-8,75$ & $-6,41$ & $-5,14$ & $-3,20$ & $-3,67$ & 2,82 & $-2,27$ & 5,02 \\
\hline PDB & 4,82 & 4,74 & 4,77 & 5,17 & 4,88 & 4,92 & 5,18 & 5,01 & 4,94 & 5,02 & 5,01 \\
\hline \multicolumn{12}{|l|}{ Sumber : BPS (diolah) } \\
\hline
\end{tabular}


Sementara itu, pertumbuhan konsumsi rumah tangga tetap kuat. Secara spasial, perbaikan PDB triwulan I 2017 ditopang oleh pertumbuhan ekonomi di Jawa terkait investasi dan di Kalimantan karena ekspor. Di sisi lain, perlambatan ekonomi terjadi di Sumatera karena penurunan investasi dan perdagangan antar daerah, serta di Sulampua dan Balinusra karena menurunnya ekspor bahan tambang.

Ekspor tercatat mengalami kenaikan pertumbuhan yang signifikan pada triwulan I 2017 sejalan dengan membaiknya permintaan maupun harga komoditas global. Pertumbuhan ekspor pada triwulan I 2017 mencapai 8,04\% (yoy), lebih tinggi dibandingkan triwulan sebelumnya yang tercatat 4,24\% (yoy). Perbaikan ini terutama ditopang oleh perbaikan ekspor komoditas primer sejalan dengan berlanjutnya perbaikan harga komoditas global seperti batubara, minyak kelapa sawit serta karet (Grafik 12).

Faktor lain yang turut mendorong positifnya kinerja ekspor nonmigas pada periode ini adalah berlanjutnya perbaikan ekonomi negara mitra dagang utama seperti Amerika Serikat, China, India dan Jepang. Selain komoditas primer, perbaikan ekspor juga didorong oleh masih positifnya kinerja ekspor manufaktur unggulan antara lain produk bahan kimia, kendaraan bermotor serta alat dan perlengkapan listrik.

Dari sisi impor, pertumbuhan impor juga mengalami peningkatan pada triwulan I 2017 menjadi 5,02\% (yoy), dibandingkan triwulan IV 2016 yang sebesar 2,82\% (yoy). Peningkatan impor terutama dipengaruhi oleh impor migas, sedangkan impor nonmigas tumbuh melambat pada triwulan I 2017 dipengaruhi oleh melambatnya impor barang konsumsi dan bahan baku (Grafik 13).

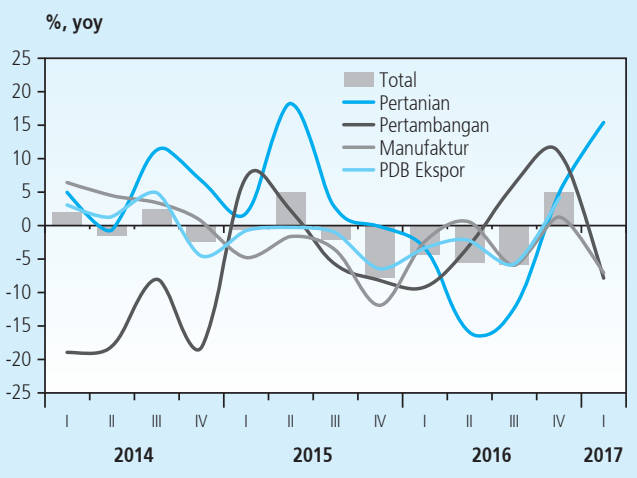

Sumber: Bank Indonesia

Grafik 12.

Pertumbuhan Ekspor Nonmigas Riil

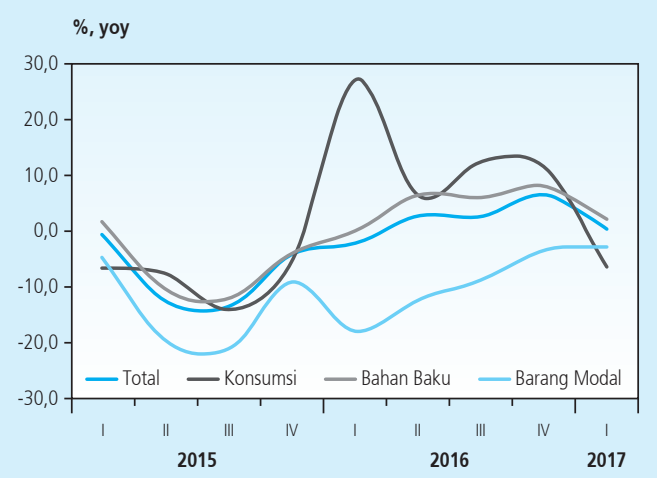

Sumber: Bank Indonesia

Grafik 13.

Pertumbuhan Impor Nonmigas Riil 
Konsumsi Pemerintah pada triwulan I 2017 tumbuh lebih tinggi dibandingkan triwulan sebelumnya. Konsumsi pemerintah tercatat tumbuh 2,71\% (yoy) pada triwulan I 2017, meningkat dari triwulan sebelumnya yang mengalami kontraksi pertumbuhan sebesar $-4,05 \%$ (yoy). Peningkatan kinerja konsumsi pemerintah tersebut terutama didorong oleh meningkatnya belanja pegawai dan belanja barang.

Meski demikian, kenaikan pertumbuhan konsumsi pemerintah tersebut lebih rendah dibandingkan periode sama tahun sebelumnya yang sebesar 3,43\% (yoy). Hal ini dipengaruhi oleh transfer ke daerah yang tumbuh negatif sejalan dengan perbaikan formula alokasi dan reformasi sistem penyaluran transfer ke daerah, sebagaimana tercermin dari lebih rendahnya realisasi Dana Alokasi Khusus (DAK) Non Fisik dan belum adanya realisasi penyaluran dana desa pada triwulan I 2017.

Meningkatnya pertumbuhan konsumsi pemerintah diikuti oleh membaiknya kinerja investasi, terutama investasi bangunan. Pertumbuhan investasi pada triwulan I 2017 sebesar $4,81 \%$ (yoy) relatif stabil dibandingkan triwulan sebelumnya (4,80\% yoy). Perbaikan kinerja investasi terutama didukung oleh investasi bangunan sejalan dengan berlanjutnya proyek infrastruktur pemerintah dan mulai meningkatnya pembangunan konstruksi sektor swasta (Grafik 14). Meningkatnya aktivitas konstruksi tercermin dari penjualan semen yang meningkat secara signifikan.

Sementara itu, kinerja investasi nonbangunan ditopang oleh penjualan mesin dan perlengkapan, serta kendaraan yang membaik. Berlanjutnya perbaikan harga komoditas dan pertumbuhan ekonomi global menjadi salah satu faktor pendorong positifnya investasi kendaraan yang tercermin pada perbaikan penjualan alat berat, terutama pada kelompok

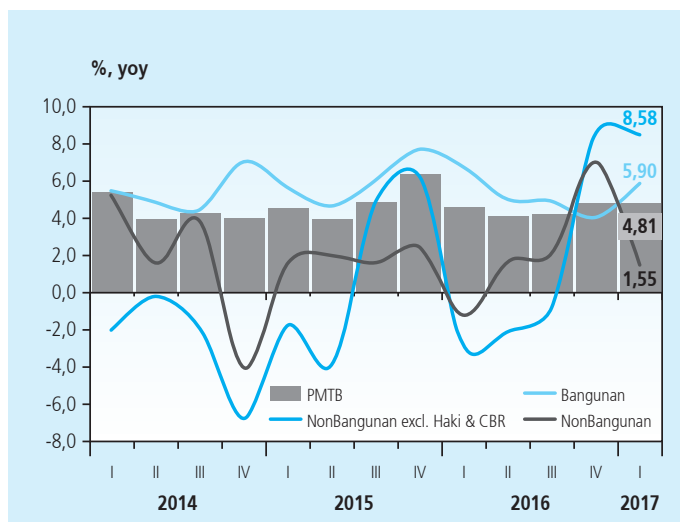

Sumber: Bank Indonesia

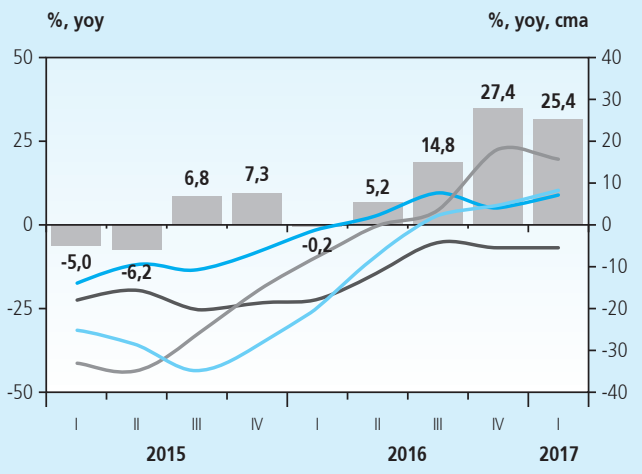

Investasi Nonbangunan (alat angkut)

- Penjualan Mobil Niaga (skala kanan)

— Impor Suku Cadang dan Peralatan untuk Alat Angkut (skala kanan)

- Impor Alat Angkut Industri (skala kanan)

Sumber: BPS, CEIC

Grafik 14.

Grafik 15.

Pertumbuhan Investasi

Impor Kendaraan dan Suku Cadang 
pertambangan dan pertanian (Grafik 15). Data realisasi investasi yang dirilis BKPM pada triwulan I 2017 juga menunjukkan hal yang sama. Pertumbuhan investasi tertinggi dicatatkan oleh subsektor pertambangan dan transportasi serta listrik, gas dan air bersih.

Sementara itu, pertumbuhan konsumsi rumah tangga (RT) tetap kuat didukung oleh optimisme konsumen. Konsumsi RT pada triwulan I 2017 tumbuh sebesar 4,93\% (yoy), relatif stabil dibandingkan triwulan sebelumnya (4,99\%, yoy). Tetap kuatnya konsumsi RT sejalan dengan keyakinan konsumen yang meningkat baik ekspektasi ke depan maupun terhadap kondisi ekonomi saat ini (Grafik 16). Namun, pertumbuhan konsumsi RT tersebut sedikit melambat dibandingkan triwulan sebelumnya sebagai pengaruh dari penyesuaian tarif listrik dan harga bahan bakar minyak yang berimbas ke daya beli masyarakat. Hal tersebut terindikasi dari penjualan ritel yang melambat pada seluruh komponen (Grafik 17). Penjualan mobil dan motor juga mengalami penurunan pada triwulan I-2017 dibandingkan triwulan sebelumnya.

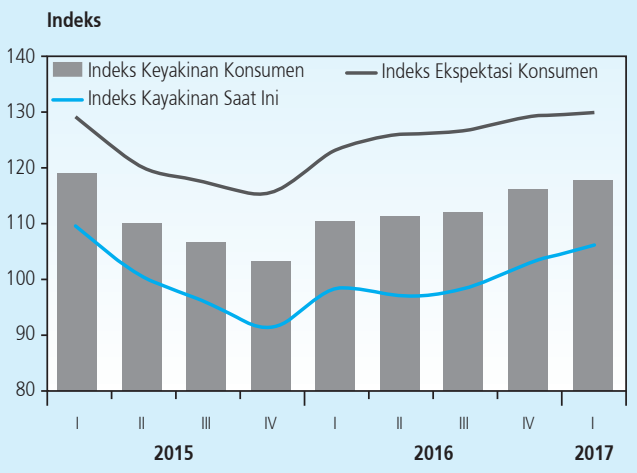

Sumber: Bank Indonesia

Grafik 16. Indeks Keyakinan Konsumen



Sumber: Bank Indonesia

Grafik 17. Penjualan Ritel dan Kendaraan Bermotor

Dari sisi Lapangan Usaha (LU), pertumbuhan ekonomi pada triwulan I 2017 ditopang baik oleh membaiknya kinerja sektor tradable maupun nontradable. Membaiknya permintaan global menjadi salah satu faktor utama yang mendorong perbaikan sektor tradable khususnya pada lapangan usaha industri. Meski demikian, pada sisi lain lapangan usaha pertambangan justru mengalami perlambatan sebagai pengaruh dari penurunan produksi dan negosiasi ijin ekspor (Tabel 2).

Sementara itu, lapangan usaha Pertanian tumbuh lebih tinggi bersumber dari peningkatan produksi di subsektor tanaman pangan dan perkebunan, seiring dengan panen raya yang berlangsung hampir serentak serta membaiknya harga komoditas Crude Palm Oil (CPO). Dari sektor nontradable, peningkatan kinerja yang signifikan terjadi pada lapangan usaha 
Perdagangan, Hotel, dan Restoran (PHR) sebagai pengaruh dari perdagangan ekspor-impor. Demikian halnya dengan kinerja lapangan usaha Konstruksi yang meningkat, seiring dengan semakin membaiknya kinerja investasi bangunan. Sejalan dengan transaksi ekspor-impor yang meningkat, sektor PHR khususnya pada subsektor perdagangan mengalami peningkatan di tengah masih relatif lemahnya perdagangan ritel domestik.

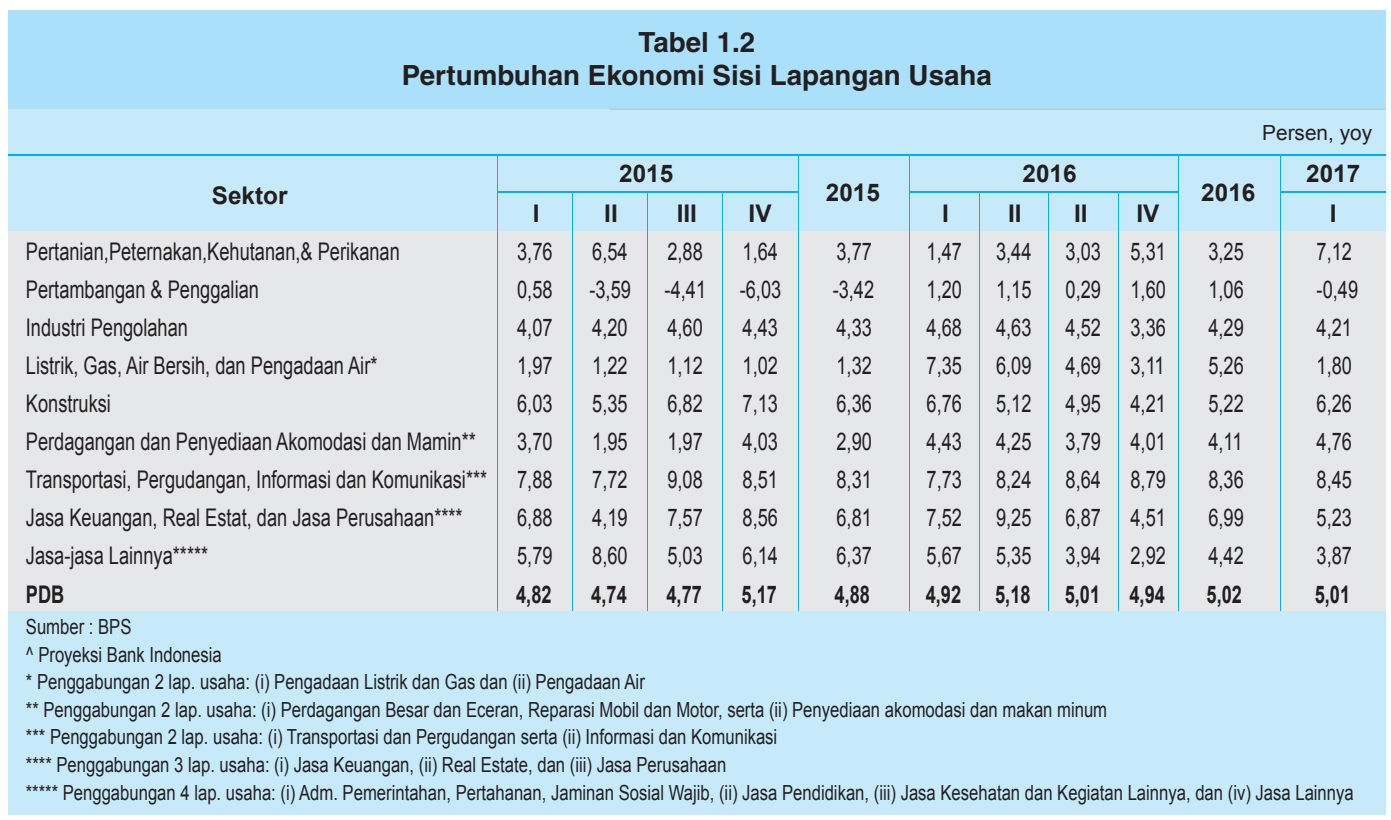

Secara spasial, pertumbuhan ekonomi nasional didukung oleh meningkatnya pertumbuhan ekonomi kawasan Jawa terkait investasi dan Kalimantan karena ekspor (Gambar 1). Pertumbuhan ekonomi Jawa pada triwulan I 2017 tumbuh meningkat sebesar 5,66\% (yoy) dari sebelumnya 5,45\% (yoy), didorong oleh membaiknya konsumsi pemerintah sejalan dengan pelaksanaan Pilkada yang dilaksanakan serentak pada Februari 2017, serta meningkatnya investasi baik oleh pemerintah terkait proyek infrastruktur serta oleh swasta terutama industri manufaktur.

Perekonomian Kalimantan tumbuh meningkat dari 2,22\% (yoy) pada triwulan IV 2016 menjadi 4,92\% (yoy) pada triwulan I 2017 didorong oleh perbaikan kinerja ekspor. Sementara itu, ekonomi Sumatera tumbuh melambat dari 4,49\% (yoy) pada triwulan sebelumnya menjadi 4,05\% (yoy), disebabkan oleh perlambatan investasi khususnya terjadi untuk investasi non-bangunan. Meski demikian, meningkatnya kinerja ekspor khususnya ekspor komoditas dan konsumsi rumah tangga, serta membaiknya konsumsi pemerintah mampu menopang pertumbuhan ekonomi Sumatera di kisaran 4\% (yoy). Di sisi lain, terdapat tekanan kinerja ekspor khususnya di wilayah Balinusra dan Sulampua terutama terkait dengan menurunnya ekspor mineral tambang dari NTB dan Papua. 


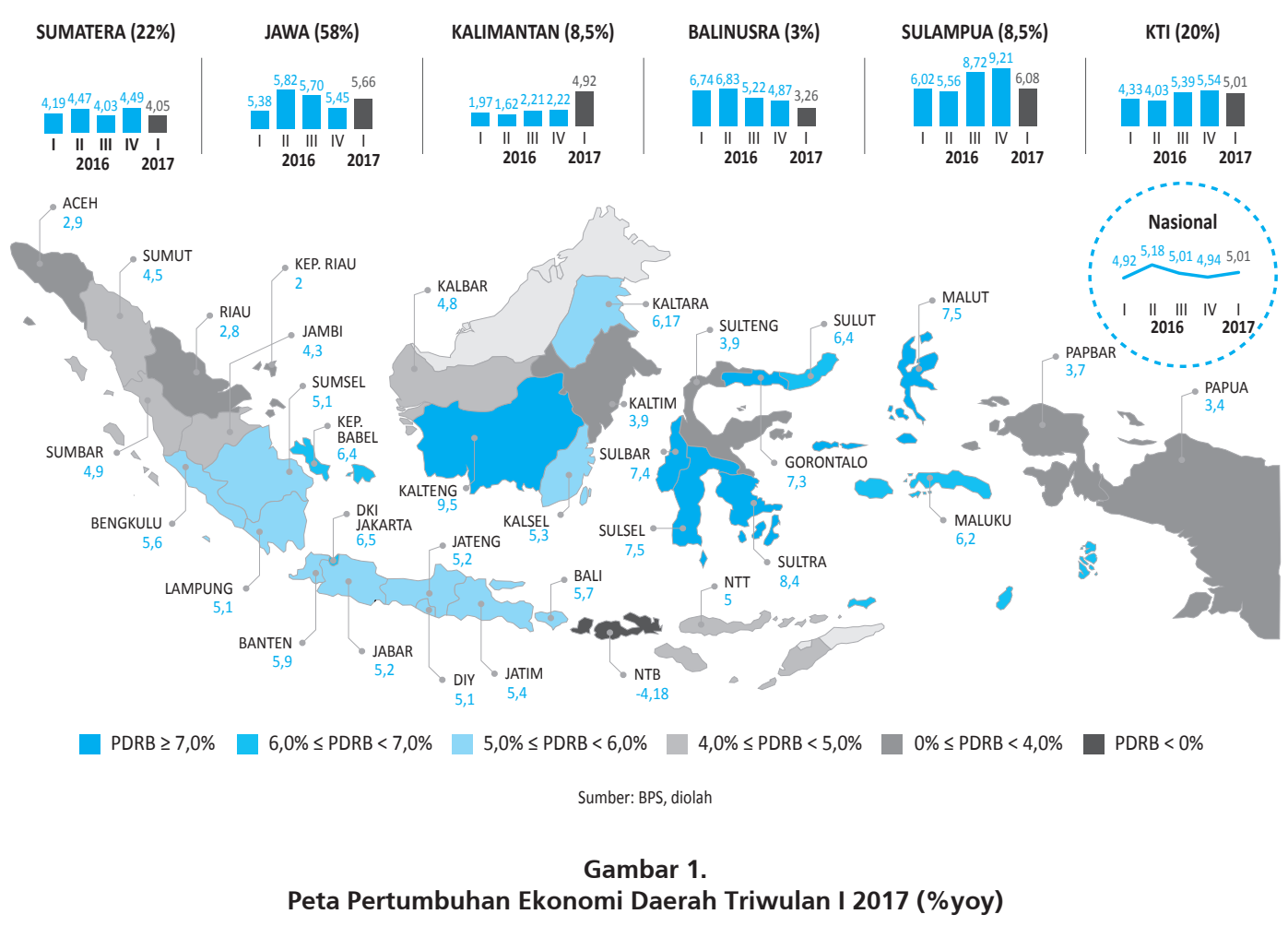

\subsection{Neraca Pembayaran Indonesia}

Neraca Pembayaran Indonesia (NPI) triwulan I 2017 kembali mencatat surplus, didukung oleh surplus transaksi modal dan finansial. Surplus NPI tercatat 4,5 miliar dolar AS, relatif sama dengan surplus pada triwulan sebelumnya, tetapi jauh lebih baik dibandingkan triwulan I 2016 yang mengalami defisit 0,3 miliar dolar AS. Surplus NPI yang berlanjut pada triwulan I 2017 ditopang oleh tingginya surplus transaksi modal dan finansial yang melampaui defisit transaksi berjalan (Grafik 18).

Meningkatnya surplus transaksi modal dan finansial sejalan dengan membaiknya pertumbuhan ekonomi dan persepsi positif terhadap prospek perekonomian. Surplus transaksi modal dan finansial pada triwulan 12017 mencapai 7,9 miliar dolar AS, lebih besar dibandingkan dengan surplus pada triwulan IV 2016 yang sebesar 7,6 miliar dolar AS maupun surplus pada triwulan I 2016 yang sebesar 4,2 miliar dolar AS (Grafik 19).

Peningkatan ini terutama didorong oleh derasnya aliran masuk modal investasi portofolio pada instrumen berdenominasi rupiah (SUN, SPN, dan saham) dan adanya penerbitan sukuk global pemerintah. Peningkatan surplus transaksi modal dan finansial lebih lanjut tertahan oleh penurunan surplus investasi langsung, terutama karena outflow investasi langsung sektor migas, dan defisit investasi lainnya khususnya karena penempatan aset sektor swasta di luar negeri. 


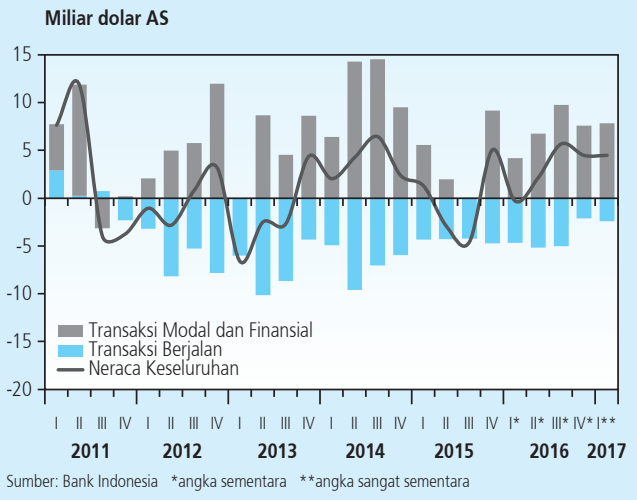

Grafik 18.

Neraca Pembayaran Indonesia
Miliar Dolar AS

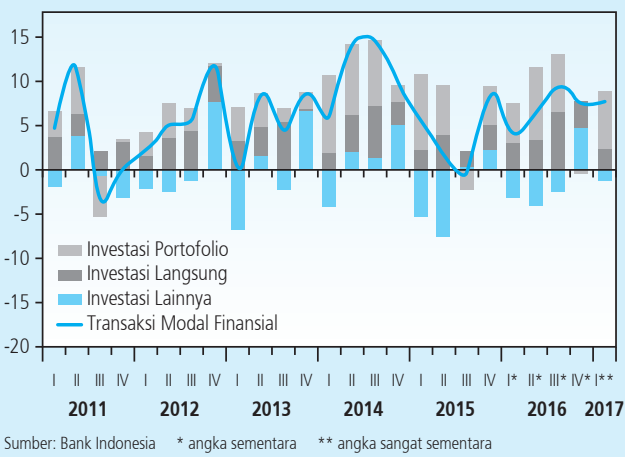

Grafik 19.

Transaksi Modal dan Finansial

Sementara itu, defisit transaksi berjalan meningkat didorong oleh meningkatnya defisit neraca perdagangan migas dan pendapatan primer (Grafik 20). Defisit transaksi berjalan pada triwulan I 2017 tercatat 2,4 miliar dolar AS (1,0\% PDB), meningkat dari 2,1 miliar dolar AS (0,9\% PDB) pada triwulan IV 2016, namun jauh lebih rendah jika dibandingkan dengan defisit pada triwulan I 2016 yang sebesar 4,7 miliar dolar AS (2,1\% PDB). Peningkatan defisit transaksi berjalan pada triwulan I 2017 terutama akibat naiknya defisit neraca perdagangan migas dan pendapatan primer. Peningkatan defisit neraca perdagangan migas dipengaruhi oleh naiknya harga minyak dunia di tengah penurunan lifting minyak, sementara kenaikan defisit neraca pendapatan primer mengikuti jadwal pembayaran bunga surat utang pemerintah yang lebih tinggi dan meningkatnya pembayaran pendapatan investasi langsung (Grafik 21). Peningkatan

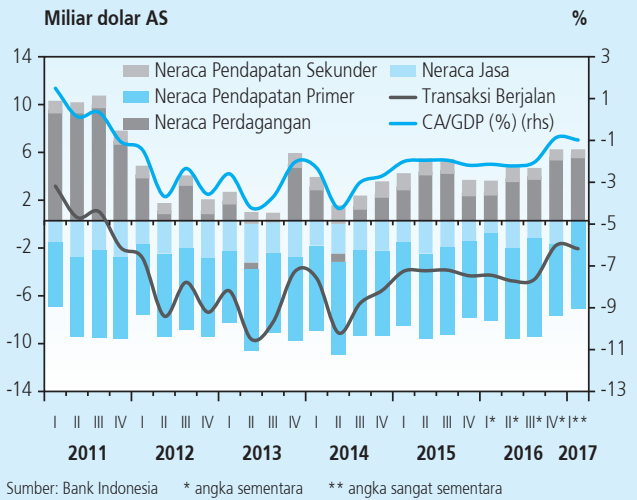

Grafik 20. Neraca Transaksi Berjalan
Miliar Dolar AS

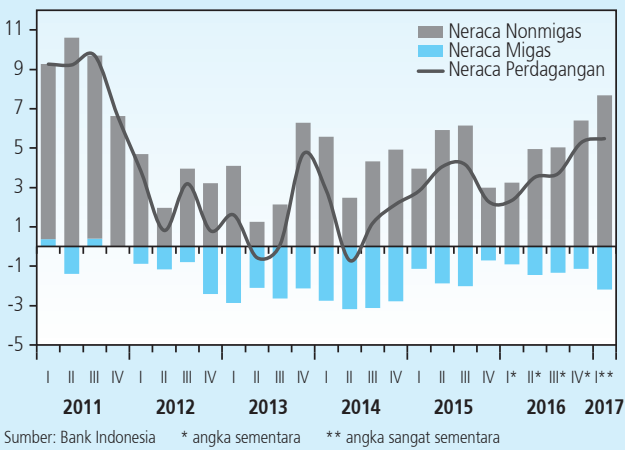

Grafik 21. Neraca Perdagangan 
defisit transaksi berjalan lebih lanjut tertahan oleh kenaikan surplus neraca perdagangan nonmigas yang ditopang meningkatnya ekspor nonmigas sejalan dengan berlanjutnya kenaikan harga komoditas dan menurunnya defisit neraca jasa terutama karena naiknya surplus jasa perjalanan.

Posisi cadangan devisa pada akhir triwulan I 2017 tercatat 121,8 miliar dolar AS, meningkat dari periode akhir triwulan sebelumnya yang sebesar 116,4 miliar dolar AS (Grafik 22). Peningkatan tersebut terutama dipengaruhi oleh penerimaan devisa, antara lain berasal dari penerimaan pajak dan devisa ekspor migas bagian pemerintah serta hasil lelang Surat Berharga Bank Indonesia (SBBI) valas. Penerimaan devisa tersebut melampaui kebutuhan devisa untuk pembayaran utang luar negeri pemerintah dan SBBI valas jatuh tempo. Posisi cadangan devisa per akhir Maret 2017 tersebut cukup untuk membiayai 8,9 bulan impor atau 8,6 bulan impor dan pembayaran utang luar negeri pemerintah, serta berada di atas standar kecukupan internasional sekitar 3 bulan impor. Bank Indonesia menilai cadangan devisa tersebut mampu mendukung ketahanan sektor eksternal dan menjaga kesinambungan pertumbuhan ekonomi Indonesia ke depan.

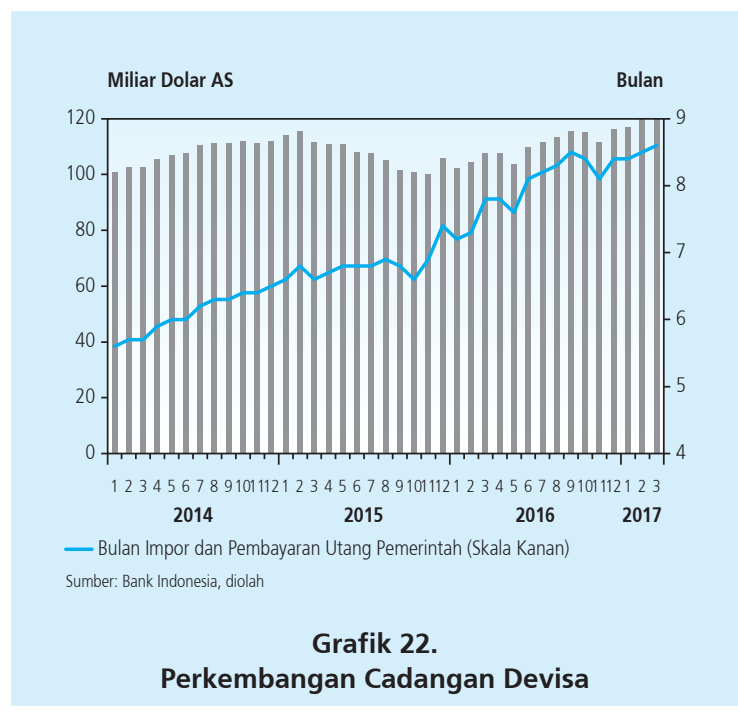

\subsection{Nilai Tukar Rupiah}

Nilai tukar rupiah bergerak menguat sepanjang triwulan I 2017 disertai volatilitas yang lebih rendah dibanding negara peers. Pada triwulan I 2017, secara point to point rupiah menguat sebesar 1,10\% menjadi Rp13.326 per dolar AS (Grafik 23). Penguatan rupiah pada triwulan I 2017 didukung oleh kondisi domestik yang cukup solid ditengah sentimen negatif terhadap US dolar dan membaiknya risiko pasar keuangan global. Volatilitas Rupiah pada triwulan I 2017 
tercatat paling rendah dibandingkan negara peers yaitu Lira (Turki), Rand (Afrika Selatan), Real (Brazil), Won (Korea Selatan), Bath (Thailand), Rupee (India), Singapore Dollar (Singapura), Peso (Filipina) dan Ringgit (Malaysia) (Grafik 24).

Pada April 2017 nilai tukar rupiah bergerak relatif stabil. Hingga akhir April 2017, rupiah menguat sebesar 1,07\% (ytd) menjadi Rp13.329 per dolar AS (Grafik 25). Di sisi eksternal, berlanjutnya penguatan rupiah dipengaruhi oleh meningkatnya sentimen negatif terhadap arah kebijakan perekonomian AS dan kenaikan pertumbuhan Tiongkok yang mendorong berlanjutnya aliran modal asing masuk ke negara EM termasuk Indonesia. Sementara di sisi domestik, penguatan rupiah didukung oleh meningkatnya cadangan devisa pada akhir Maret 2017 sejalan dengan perbaikan outlook sovereign rating dan sentimen positif terhadap kondisi dan prospek perekonomian Indonesia. Berlanjutnya penguatan rupiah pada April 2017 juga disertai volatilitas yang tetap rendah dibanding negara peers (Grafik 26).

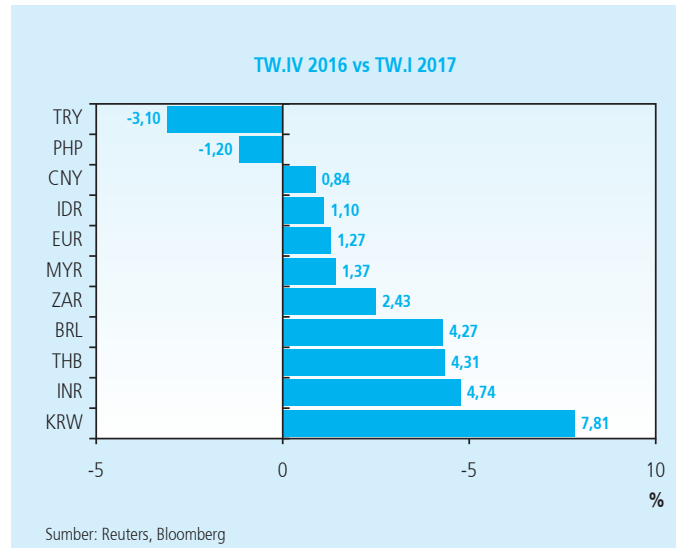

Grafik 23.

Nilai Tukar Kawasan

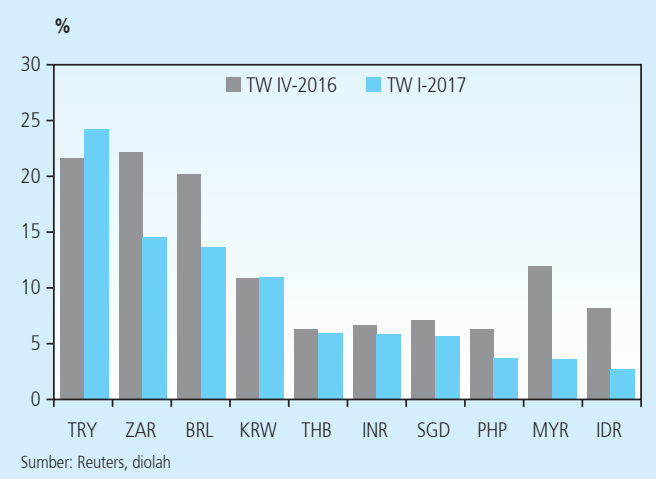

Grafik 25.

Volatilitas Triwulanan

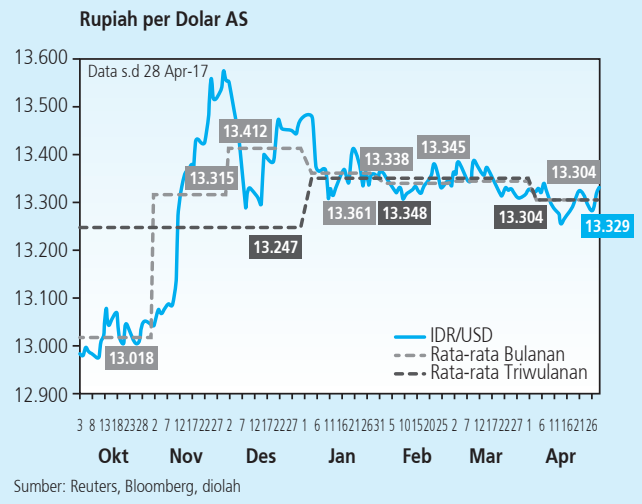

Grafik 24.

Nilai Tukar Rupiah

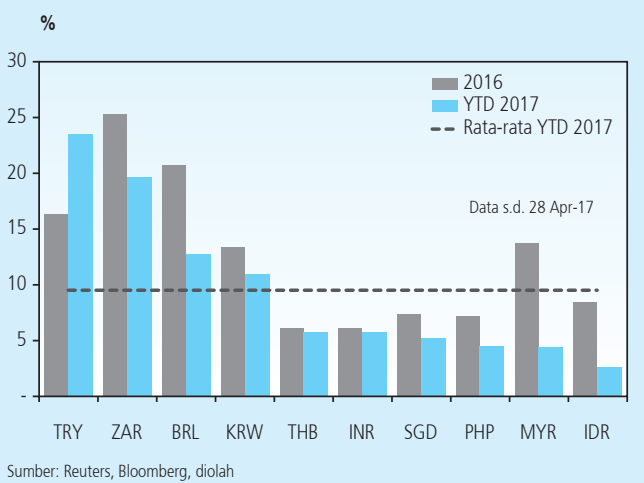

Grafik 26.

Volatilitas Bulanan 


\subsection{Inflasi}

Inflasi pada triwulan I 2017 tetap terkendali dalam kisaran sasaran inflasi 2017 yaitu 4 4 1\%, meski sedikit lebih tinggi dibanding periode triwulan sebelumnya. Pada akhir triwulan I 2017 , realisasi inflasi IHK tercatat sebesar 3,61\% (yoy) atau lebih tinggi dibanding periode akhir triwulan IV 2016 yang sebesar 3,02\% (yoy). Tekanan kenaikan inflasi di periode triwulan ini bersumber dari kelompok administered prices, terutama terkait penerapan sejumlah kebijakan tarif di awal tahun 2017. Sementara itu, inflasi inti relatif stabil dan inflasi pangan bergejolak (volatile foods) tercatat lebih rendah. Secara bulanan, sepanjang periode triwulan I 2017 tekanan inflasi yang cukup tinggi hanya terjadi pada bulan Januari yakni sebesar 0,97\% (mtm) karena didorong oleh penerapan kenaikan tarif perpanjangan STNK dan tarif listrik. Tekanan inflasi kembali menurun pada Februari 2017 menjadi sebesar 0,23\% (mtm) dan pada Maret 2017 bahkan mengalami deflasi $0,02 \%(\mathrm{mtm})$ seiring dengan melimpahnya pasokan pangan.

Memasuki awal triwulan II 2017, IHK kembali mengalami inflasi namun masih berada pada level yang cukup rendah yakni sebesar 0,09\% (mtm) pada April 2017. Realisasi inflasi IHK pada awal triwulan II 2017 dipengaruhi oleh kenaikan inflasi pada kelompok administered price (AP), sementara inflasi inti tercatat cukup rendah, sedangkan volatile foods bahkan masih tercatat mengalami deflasi. Secara tahunan, inflasi IHK pada April 2017 tercatat sebesar 4, 17\% (yoy), masih sejalan dengan kisaran sasaran inflasi 2017 (Grafik 27).

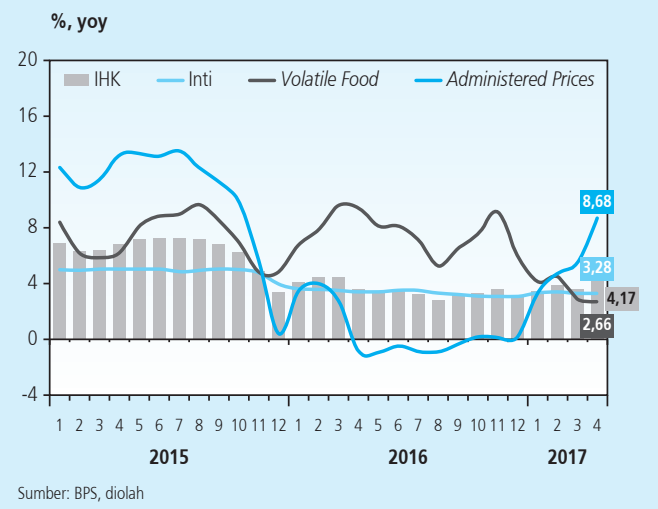

Grafik 27.

Perkembangan Inflasi Tahunan

Inflasi kelompok administered prices pada April 2017 tercatat 1,27\% (mtm), meningkat dibanding bulan sebelumnya yang sebesar 0,37\% ( $\mathrm{mtm})$. Tekanan pada inflasi administered prices terutama didorong oleh penerapan penyesuaian tarif listrik tahap dua untuk pelanggan pascabayar daya 900 VA nonsubsidi dan kenaikan tarif angkutan udara karena meningkatnya 
permintaan akibat libur panjang (Tabel 3). Selain itu, kenaikan harga bahan bakar khusus (BBK) seperti Pertalite, Pertamax, Pertamax Turbo, Dexlite dan Pertamina Dex masing-masing sebesar Rp100/liter turut mendorong kenaikan inflasi kelompok administered prices pada bulan April 2017. Demikian pula dengan kenaikan cukai rokok yang turut berkontribusi pada naiknya inflasi kelompok administered prices di periode awal triwulan II 2017. Secara tahunan, inflasi administered prices pada April 2017 tercatat berada pada level yang cukup tinggi yakni sebesar 8,68\% (yoy) atau berada di atas realisasi bulan sebelumnya yang sebesar 5,50\% (yoy) (Grafik 28).

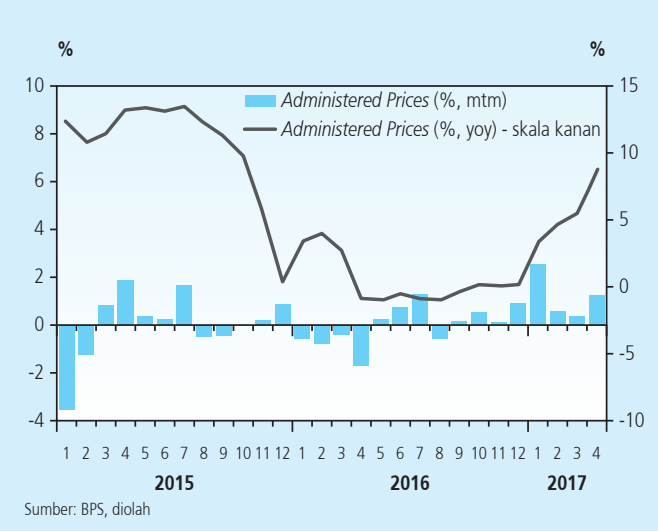

Grafik 28.

Inflasi Administered prices
Tabel 3.

\section{Penyumbang Inflasi Administered Prices}

\begin{tabular}{|c|c|c|c|}
\hline No. & Komoditas & $\begin{array}{c}\text { Inflasi/Deflasi } \\
(\% \mathrm{mtm})\end{array}$ & $\begin{array}{c}\text { Sumbangan } \\
(\%)\end{array}$ \\
\hline \multicolumn{4}{|c|}{ INFLASI } \\
\hline 1 & Tarif listrik & 5,29 & 0,20 \\
\hline 2 & Angkutan udara & 1,39 & 0,02 \\
\hline 3 & Bensin & 0,39 & 0,01 \\
\hline 4 & Rokok kretek filter & 0,46 & 0,01 \\
\hline 5 & Rokok kretek & 0,73 & 0,01 \\
\hline
\end{tabular}

Sementara itu, inflasi inti pada April 2017 cukup terkendali sejalan dengan masih terbatasnya permintaan domestik, terjaganya ekspektasi inflasi, dan menguatnya nilai tukar rupiah. Inflasi Inti tercatat 0,13\% (mtm) sedikit lebih tinggi dari bulan Maret 2017 yang sebesar 0,10\% (mtm), namun masih lebih rendah dibandingkan pola historis 2010-2012 (Grafik 29). Inflasi kelompok inti pada bulan April 2017 dipengaruhi oleh tekanan pada komponen inti nontraded terutama karena naiknya tarif pulsa ponsel dan tarif sewa rumah. Sementara itu, komponen inti traded mengalami perlambatan terutama karena turunnya harga komoditas gula pasir seiring menguatnya rupiah dan turunnya harga gula di pasar global. Tekanan permintaan domestik diperkirakan masih relatif terbatas yang tercermin dari pertumbuhan M2 dan kredit konsumsi yang masih relatif rendah. Di sisi lain, hasil survey mengindikasikan mulai adanya peningkatan ekspektasi inflasi, baik di tingkat konsumen maupun di tingkat pedagang eceran, terutama dipengaruhi oleh jatuhnya Ramadhan pada Juni 2017 (Grafik 30 dan Grafik 31). Secara tahunan, inflasi inti pada April 2017 tercatat 3,28\% (yoy), relatif stabil dibanding realisasi inflasi inti di bulan sebelumnya yang sebesar 3,30\% (yoy). 


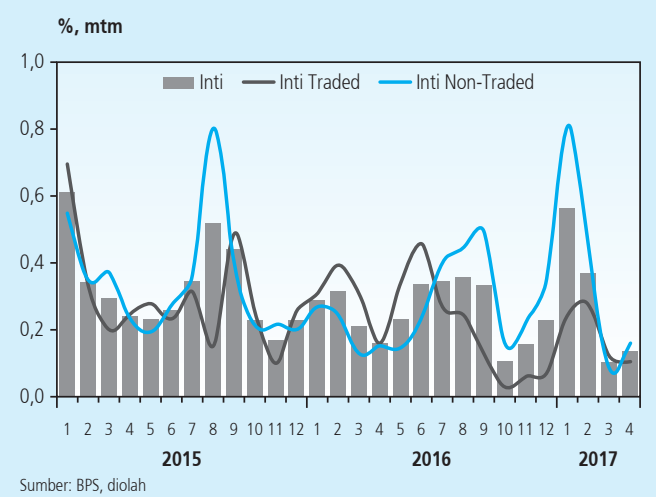

Grafik 29. Inflasi Inti

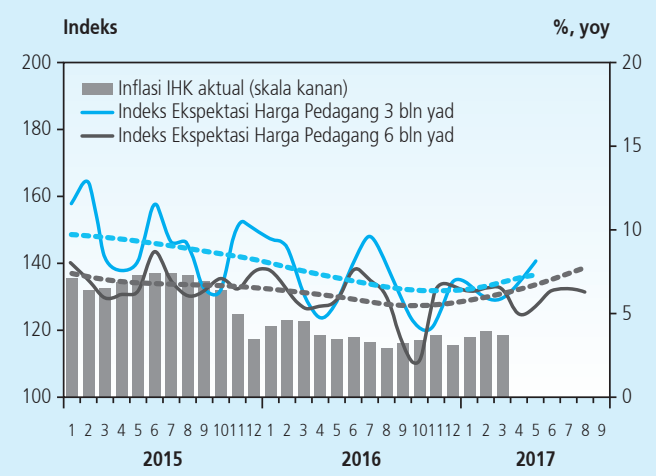

Grafik 30.

Ekspektasi Inflasi Pedagang Eceran

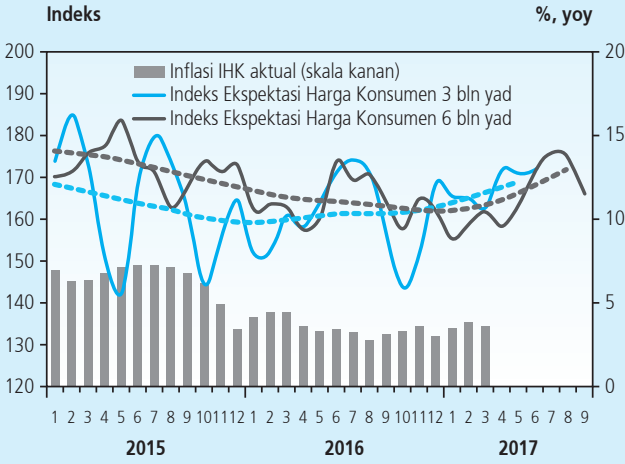

Grafik 31.

Ekspektasi Inflasi Konsumen

Inflasi kelompok volatile food pada April 2017 tercatat mengalami deflasi sebesar 1,26\% (mtm), melanjutkan deflasi pada bulan sebelumnya yang sebesar 0,77\% (mtm) (Grafik 32). Deflasi terutama bersumber dari komoditas cabai merah, cabai rawit, bawang merah, beras, daging sapi, ikan segar, telur ayam ras, dan minyak goreng. Penurunan harga pangan terjadi seiring dengan melimpahnya pasokan karena panen raya di berbagai daerah sentra produksi. Deflasi lebih lanjut tertahan oleh kenaikan harga bawang putih dan daging ayam ras yang didorong oleh mulai terbatasnya pasokan di tengah permintaan yang mulai meningkat (Tabel 4). Secara tahunan, inflasi volatile food mencapai sebesar 2,66\% (yoy), sedikit lebih rendah dibanding bulan sebelumnya yang sebesar 2,89\% (yoy). 


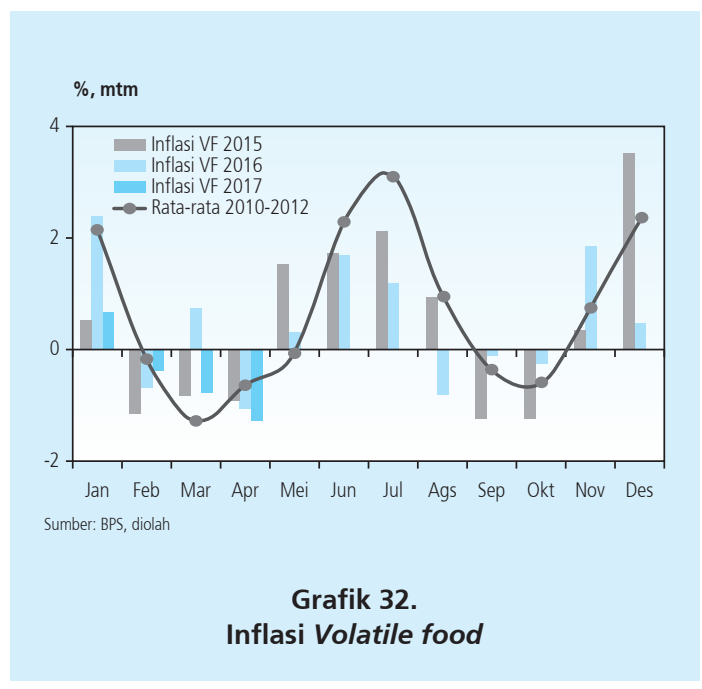

\begin{tabular}{|c|c|c|c|}
\hline \multicolumn{4}{|c|}{$\begin{array}{c}\text { Tabel } 4 . \\
\text { Penyumbang Inflasi Volatile Food }\end{array}$} \\
\hline No & Komoditas & \begin{tabular}{|} 
Inflasi/Deflasi \\
$(\% \mathrm{mtm})$
\end{tabular} & $\begin{array}{c}\text { Sumbangan } \\
(\%)\end{array}$ \\
\hline \multicolumn{4}{|c|}{ INFLASI } \\
\hline 1 & Bawang Putih & 8,38 & 0,03 \\
\hline 2 & Daging Ayam Ras & 1,54 & 0,02 \\
\hline 3 & Tomat Sayur & 10,46 & 0,02 \\
\hline \multicolumn{4}{|c|}{ DEFLASI } \\
\hline 1 & Cabai Merah & $-14,77$ & $-0,09$ \\
\hline 2 & Cabai Rawit & $-24,34$ & $-0,09$ \\
\hline 3 & Bawang Merah & $-11,71$ & $-0,08$ \\
\hline 4 & Beras & $-0,43$ & $-0,02$ \\
\hline 5 & Daging Sapi & $-0,97$ & $-0,01$ \\
\hline 6 & Ikan Segar & $-0,30$ & $-0,01$ \\
\hline 7 & Telur Ayam Ras & $-0,79$ & $-0,01$ \\
\hline 8 & Minyak Goreng & $-1,20$ & $-0,01$ \\
\hline \multicolumn{4}{|c|}{ Sumber: BPS, diolah } \\
\hline
\end{tabular}

Secara spasial, tekanan inflasi terjadi hampir di seluruh wilayah kecuali Sumatera yang tercatat mengalami deflasi (Gambar 2). Secara berurutan, inflasi tertinggi terjadi di KTI (0,12\%; mtm), kemudian Jawa $(0,12 \%$; mtm). Inflasi KTI terutama disumbang oleh Kalimantan yang dpengaruh oleh kenaikan tarif listrik, bensin dan tomat sayur. Sementara peningkatan tekanan inflasi di Jawa, disumbang oleh inflasi yang berlangsung di hampir seluruh provinsi di Jawa, kecuali DKI Jakarta, terutama bersumber dari kenaikan tarif angkutan udara, harga rokok dan bawang putih serta daging ayam ras Sejumlah daerah dengan inflasi tertinggi adalah Kepulauan

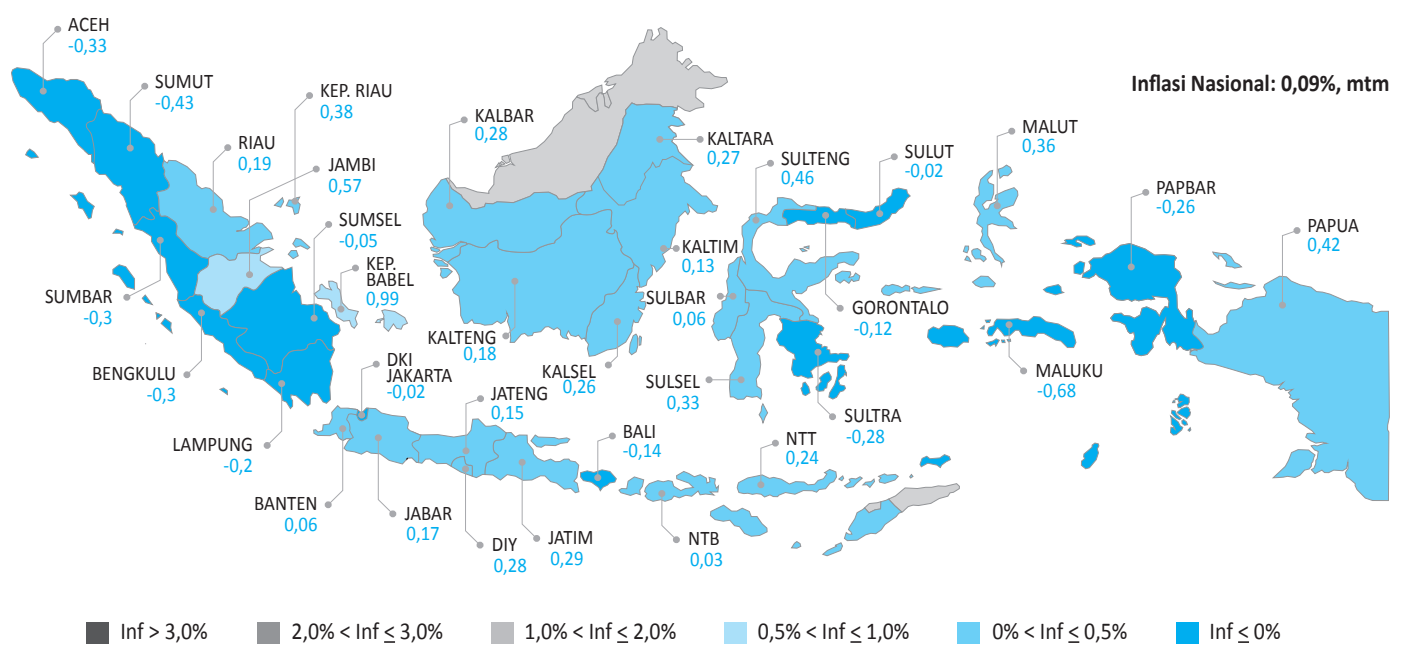

Sumber: BPS, diolah

Gambar 2. Peta Inflasi Regional, April 2017 (\%, mtm) 
Bangka Belitung (0,99\%; mtm), Jambi (0,57\%; mtm), Sulawesi Tengah (0,46\%; mtm), Papua $(0,42 \% ; \mathrm{mtm})$, dan Kepulauan Riau $(0,38 \% ; \mathrm{mtm})$. Secara tahunan (yoy), sebagian besar daerah masih mencatatkan inflasi di dalam rentang sasaran $4 \pm 1 \%$, kecuali beberapa provinsi yaitu Kepulauan Bangka Belitung (8,37\%; yoy), Bengkulu (6,60\%; yoy), Riau (6,40\%; yoy), Kalimantan Barat (5,79\%; yoy) dan Sulawesi Tengah (5,09\%; yoy).

\section{PERKEMBANGAN MONETER, PERBANKAN, DAN SISTEM PEMBAYARAN}

\subsection{Moneter}

Transmisi pelonggaran kebijakan moneter membaik meski belum optimal sejalan dengan kehatihatian bank dalam mengelola risiko kredit. Pertumbuhan kredit dan Dana Pihak Ketiga (DPK) menunjukkan peningkatan di tengah berlanjutnya tren penurunan suku bunga DPK maupun kredit dengan level penurunan yang lebih terbatas. Kondisi tersebut didukung oleh likuiditas yang masih memadai. Pada sisi lain, pertumbuhan pembiayaan pada pasar keuangan non bank juga mulai searah dengan pertumbuhan kredit dan mencatatkan level tertinggi setidaknya dalam 7 tahun terakhir.

Kondisi PUAB yang stabil disertai dengan berlanjutnya tren penurunan suku bunga mengindikasikan likuiditas perbankan masih memadai. Rata-rata harian suku bunga PUAB O/N pada triwulan I 2017 tercatat 4,23\% atau turun 7 bps dibandingkan triwulan sebelumnya (4,30\%). Secara umum, suku bunga PUAB O/N sepanjang triwulan I 2017 semakin konsisten berada di dalam range koridor suku bunga yaitu 4,25\% s.d. 5,25\% (Grafik 33). Volatilitas suku bunga PUAB O/N juga jauh lebih terjaga, tercermin dari rata-rata harian spread min-max PUAB O/N yang berada pada angka 12 bps, lebih rendah dari triwulan sebelumnya pada 33 bps. Selain penurunan rata-rata harian suku bunga, volume transaksi PUAB O/N juga meningkat, memperkuat indikasi masih terjaganya likuiditas perbankan (Grafik 34).



Grafik 33.

Perkembangan Suku Bunga PUAB O/N

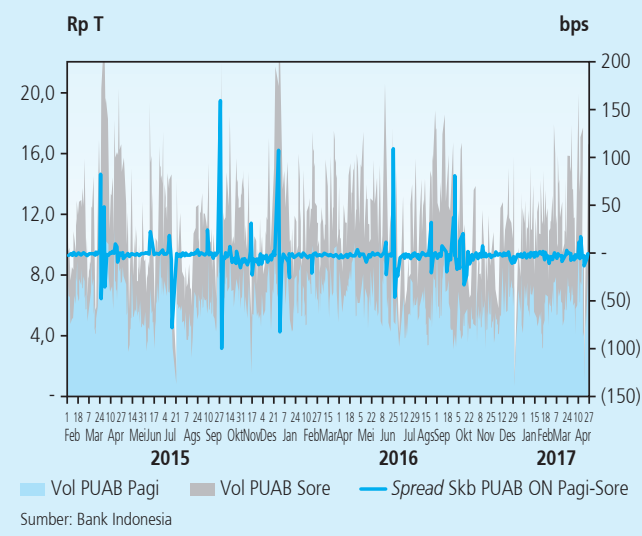

Grafik 34. Volume PUAB O/N 
Penurunan suku bunga deposito masih berlanjut pada triwulan I 2017. Rata-rata tertimbang suku bunga deposito pada triwulan I 2017 turun 11 bps (qtq) menjadi 6,61\%. Dengan demikian, sejak awal penurunan suku bunga kebijakan pada Desember 2015 penurunan suku bunga deposito sudah mencapai 133 bps. Selain suku bunga kebijakan yang menurun, membaiknya likuiditas menjadi faktor utama penurunan suku bunga deposito. Penurunan suku bunga deposito terjadi pada tenor panjang yaitu 12 bulan dan 24 bulan yang turun masingmasing 21 bps (qtq) dan 32 bps (qtq) dibanding Desember 2016.

Suku bunga kredit terus menurun dengan penurunan yang lebih besar dari suku bunga deposito. Pada triwulan I 2017, suku bunga kredit turun 14 bps (qtq), lebih dalam dari penurun suku deposito pada periode yang sama sebesar 11 bps. Sejak awal penurunan suku bunga kebijakan pada Desember 2015, suku bunga kredit telah menurun mencapai 93 bps. Penurunan suku bunga kredit terjadi pada semua jenis kredit berdasarkan penggunaan, dengan penurunan terbesar pada jenis kredit produktif yaitu kredit modal kerja (KMK) yang turun 17 bps (qtq), diikuti suku bunga kredit investasi (KI) sebesar 16 bps (qtq), dan suku bunga kredit konsumsi (KK) sebesar 11 bps (qtq) (Grafik 35).

Sementara itu, spread suku bunga relatif stabil pada triwulan 12017 . Spread suku bunga pada triwulan I 2017 sedikit menyempit didorong oleh lebih dalamnya penurunan suku bunga kredit dibandingkan dengan suku bunga deposito. Secara bulanan, spread suku bunga deposito dan kredit turun sebesar 3 bps yaitu dari 532 bps menjadi 529 bps (Grafik 36).

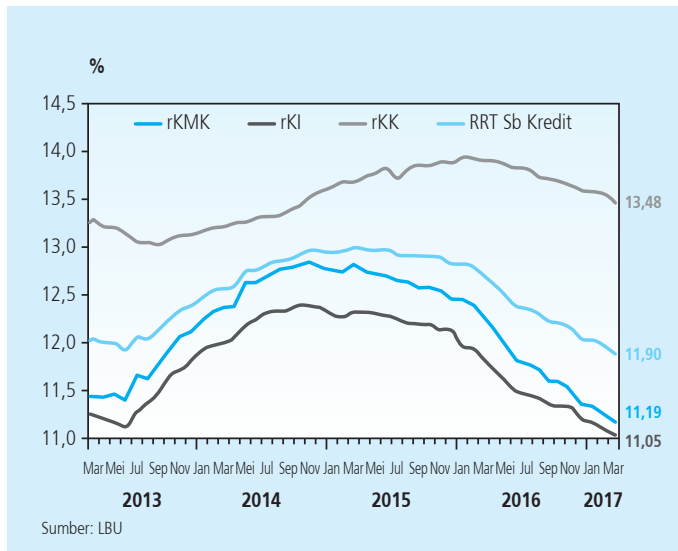

Grafik 35. Suku Bunga Kredit: KMK, KI dan KK

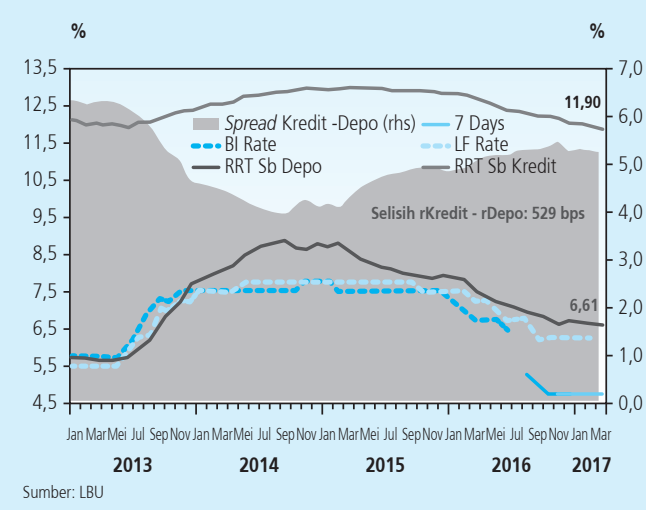

Grafik 36. Spread Suku Bunga Perbankan

Di sisi likuiditas, pertumbuhan likuiditas perekonomian M2 (uang beredar dalam arti luas) tumbuh meningkat. Pertumbuhan M2 pada Triwulan I 2017 sebesar 10,0\% (yoy), lebih tinggi dibandingkan pertumbuhan pada Triwulan I 2016 sebesar 7,4\% (yoy). Berdasarkan komponen pembentuknya, peningkatan M2 pada Triwulan I 2017 terutama disumbang oleh pertumbuhan 
uang kuasi. Pertumbuhan komponen uang kuasi tercatat sebesar 8,6\% (yoy), lebih tinggi dibandingkan periode yang sama pada tahun sebelumnya sebesar 6,3\% (yoy) (Grafik 37). Sementara itu, M1 tumbuh 14,2\% (yoy), lebih tinggi dibandingkan Triwulan I 2016 sebesar $11,2 \%$ (yoy). Pertumbuhan M1 disumbang oleh dua komponen pembentuknya, uang kartal dan simpanan giro Rupiah (Grafik 38). Berdasarkan faktor yang memengaruhinya, peningkatan M2 disumbang oleh kenaikan NFA yang tercatat tumbuh sebesar 17,6\% (yoy), jauh lebih tinggi dibandingkan Triwulan I 2016 yang mengalami kontraksi sebesar 0,2\% (yoy) (Grafik 39).

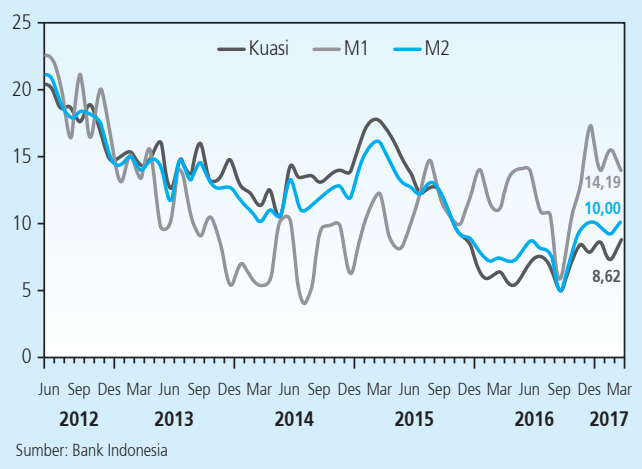

Grafik 37.

Pertumbuhan M2 dan Komponennya

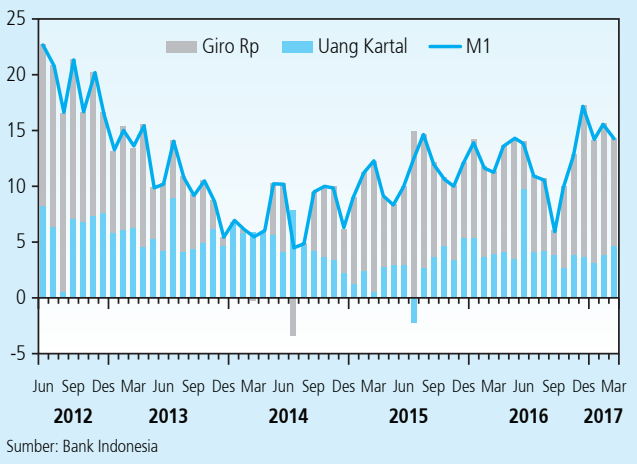

Grafik 38.

Pertumbuhan M1 dan Komponennya

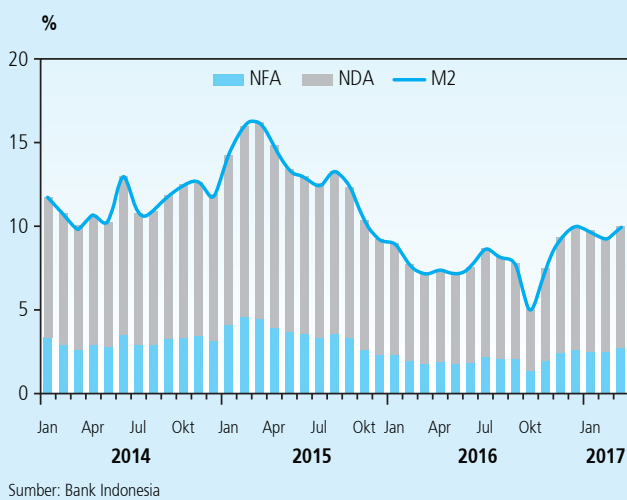

Grafik 39. Pertumbuhan M2 dan Faktor-faktor yang Mempengaruhinya

\subsection{Industri Perbankan}

Ketahanan industri perbankan tetap kuat didukung oleh tingginya rasio kecukupan modal di tengah risiko kredit yang cenderung tinggi. Ketahanan permodalan industri perbankan masih berada pada level yang cukup kuat dan jauh diatas threshold-nya seiring dengan terjaganya 
profitabilitas perbankan. Permodalan perbankan atau Capital Adequacy Ratio (CAR) mencapai 22,7\% pada akhir Triwulan I 2017. Level kecukupan permodalan perbankan yang terus meningkat dibandingkan dengan tahun-tahun sebelumnya diperkirakan mampu untuk menahan dampak negatif dari peningkatan risiko kredit dan mengantisipasi kebutuhan pemenuhan Capital Surcharge serta Countercyclical Capital Buffer (Grafik 1.40). Sementara itu, risiko kredit yang tercermin dari rasio Non Performing Loan (NPL) masih terjaga meski mengalami sedikit peningkatan. NPL berada pada level 3,04\% pada akhir triwulan I 2017, sedikit lebih tinggi dari 2,93\% pada akhir tahun 2016.

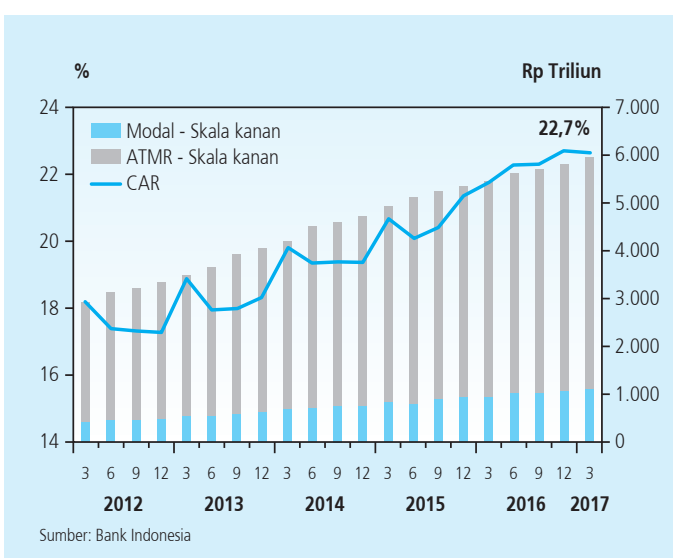

Grafik 40.

Permodalan Industri Perbankan

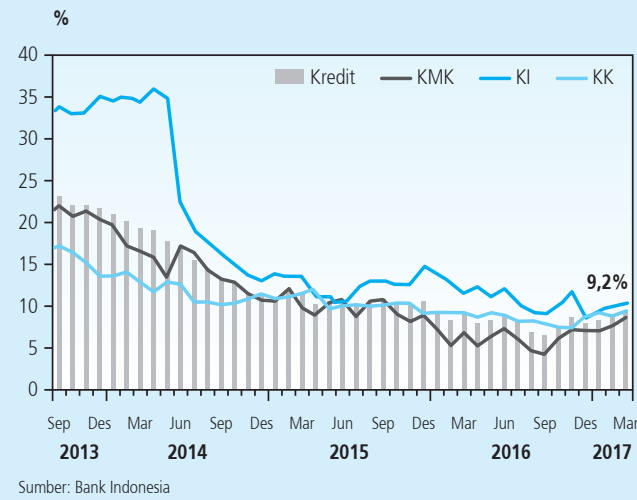

Grafik 41.

Pertumbuhan Kredit Menurut Penggunaan

Pertumbuhan kredit pada triwulan I 2017 meningkat. Kredit tumbuh 9,2\% (yoy) pada triwulan I 2017 didorong oleh pertumbuhan kredit investasi (KI) dan kredit konsumsi (KK). Sementara, itu, pertumbuhan kredit modal kerja (KMK) mencapai 8,6\% (yoy), yang merupakan jenis kredit dengan pangsa terbesar, masih berada di bawah pertumbuhan kredit total (Grafik 41). Berdasarkan sektor ekonomi, pertumbuhan kredit triwulan I 2017 meningkat terjadi di hampir seluruh setor, dengan kenaikan tertinggi pada kredit ke sektor perdagangan (yang memiliki porsi kredit terbesar) yakni sebesar 7,3\% (yoy) dari 6,4\% (yoy) di triwulan IV 2016. Penyaluran kredit ke sektor industri yang memiliki porsi kredit cukup besar meningkat menjadi sebesar 3,7\% (yoy), terakselerasi dibandingkan triwulan sebelumnya (2,8\% yoy). Kredit sektor konstruksi juga meningkat sebesar 26,4\% (yoy), naik dibandingkan triwulan sebelumnya yang sebesar 24,2\% (yoy). Sementara, penyaluran kredit pada sektor Pertambangan terus melanjutkan tren pertumbuhan positif menjadi 3,3\% (yoy), meningkat pesat dibandingkan triwulan IV 2016 yang mengalami kontraksi 6,61\% (yoy) (Grafik 42).

Dana Pihak Ketiga (DPK) pada triwulan I 2017 tumbuh sebesar 10,0\% (yoy), meningkat dibandingkan triwulan sebelumnya sebesar 9,6\% (yoy) (Grafik 43). Berdasarkan jenisnya, 
pertumbuhan DPK pada triwulan I 2017 terutama bersumber dari kenaikan pertumbuhan deposito dan tabungan, sementara pertumbuhan giro masih cenderung stabil.

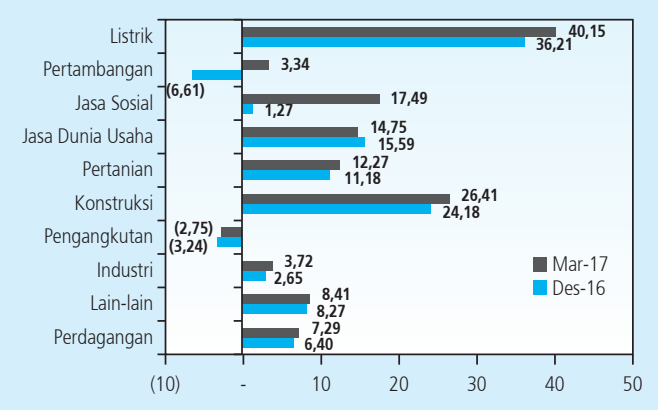

Sumber: Bank Indonesia

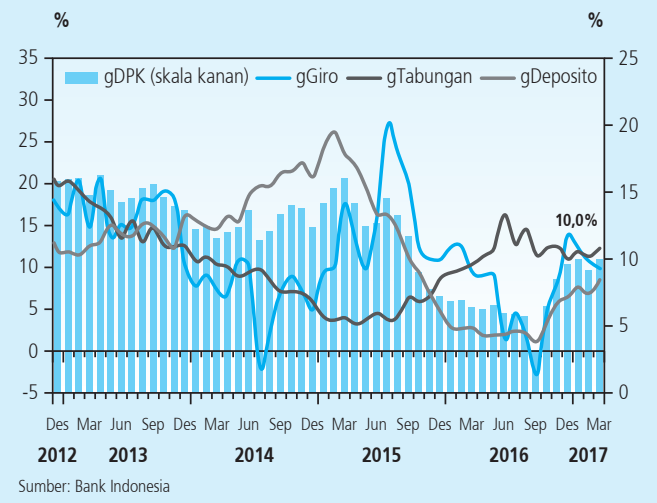

Grafik 43.

Pertumbuhan DPK

\subsection{Pasar Saham dan Pasar Surat Berharga Negara}

Pasar saham domestik pada triwulan I 2017 dan hingga April 2017 berada dalam tren yang menguat, terutama dipengaruhi oleh sentimen domestik. IHSG pada akhir triwulan I 2017 tumbuh positif dengan ditutup pada level 5.568,11, naik 5,12\% (qtq) dari posisi akhir tahun 2016 pada level 5.296,71. Pada penutupan akhir April 2017, IHSG berada di level 5.685,30 atau naik 117 poin $(2,10 \%, \mathrm{mtm})$. IHSG sempat beberapa kali menembus rekor tertingginya (all time high) hingga sempat menyentuh rekor tertinggi di level 5.726,53 (26 April 2017). Kinerja positif IHSG ditengah sentimen global yang masih mixed terutama dipengaruhi oleh fundamental ekonomi domestik yang solid sebagaimana tercermin dari beberapa indikator ekonomi domestik yang positif. Indikator positif tersebut antara lain data inflasi Maret yang lebih baik dibandingkan ekspektasi pasar, inflasi April yang diperkirakan masih terjaga, data cadangan devisa yang naik dan laporan keuangan triwulan I 2017 dari beberapa emiten berkapitalisasi besar seperti WIKA, WSKT, dan TLKM yang lebih baik dari perkiraan. Meski diwarnai aksi profit taking seiring concern valuasi IHSG yang dianggap cukup tinggi dan situasi politik dalam negeri, namun optimisme investor terhadap fundamental ekonomi RI menahan pelemahan lebih lanjut.

Kinerja saham domestik sejalan dengan pergerakan bursa saham global yang juga tumbuh positif. Secara umum, bursa global bergerak positif pada triwulan I 2017. Bursa global kembali bergerak positif dengan pertumbuhan 1,1\% (mtm) pada April 2017 (Grafik 44). Dibandingkan dengan bursa regional, kinerja IHSG pada April 2017 masih tercatat cukup baik dengan pertumbuhan di bawah bursa Filipina yang tumbuh paling tinggi sebesar 4,8\% disusul 
Indonesia dan Hong Kong yang masing-masing tumbuh 2,10\%. Penguatan bursa regional diantaranya didorong oleh rilis data manufaktur Jepang yang positif dan optimisme investor terhadap pertemuan Trump-Ji Xinping yang cukup positif.

Menguatnya IHSG tercermin dari kinerja positif sebagian besar indeks sektoral. Kenaikan terutama terjadi pada sektor perdangan yang tumbuh 3,9\% dan disusul sektor infrastruktur yang tumbuh 3,8\% (Grafik 45). Kinerja positif saham sektor perdagangan sejalan dengan kenaikan harga batubara dunia akibat terganggunya produksi dan pengiriman batubara yang disebabkan oleh gangguan cuaca yang mempengaruhi produksi Australia. Sementara penguatan sektor infrastruktur didorong oleh rilis data emiten sektor yang membaik. Kenaikan harga saham berbasis konstruksi seperti Wijaya Karya dan Waskita Karya dipengaruhi oleh sentimen positif rilis laporan keuangan triwulan I 2017 yang sesuai ekspektasi pasar. Sedangkan koreksi pada saham di sektor pertanian sebesar -2,3\% dipicu oleh futures CPO yang melemah akibat naiknya output Malaysia sehingga menyebabkan tertekannya saham pertanian.

Kepemilikan saham oleh nonresiden meningkat. Investor non residen tercatat melakukan net beli sebesar Rp13,97 triliun pada April 2017, naik dibandingkan bulan sebelumnya dengan net beli sebesar Rp10,12 triliun sehingga secara total dana asing asing yang tercatat masuk ke pasar saham domestik sebesar Rp22,32 triliun. Dengan perkembangan tersebut, porsi investor nonresiden di pasar saham tercatat meningkat menjadi sebesar 39,5\% (mtm).

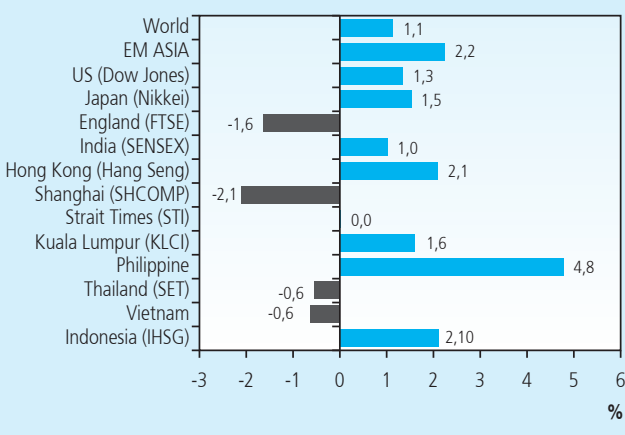

Sumber: Bloomberg

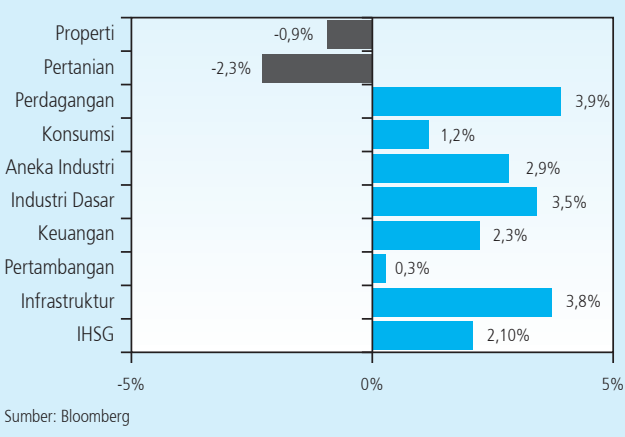

Grafik 45.

Perkembangan Indeks Sektoral Triwulan I 2017

HSG dan Indeks Bursa Global (mtm)

Sejalan dengan kinerja pasar saham, kinerja pasar SBN juga tercatat positif sepanjang triwulan I 2017 dan April 2017. Yield SBN masih melanjutkan tren penurunan meski dengan magnitude yang lebih kecil (Grafik 46). Secara keseluruhan, yield pada April 2017 tercatat turun sebesar 8 bps dari 7,10\% menjadi 7,02\% (mtm). Pada periode yang sama, yield jangka pendek, menengah dan panjang masing-masing turun sebesar 14 bps, 7 bps dan 1 bps menjadi 
6,54\%, 7,00\% dan 7,72\%. Sementara itu, yield benchmark 10 tahun relatif stabil di level 7,05\%. Tren positif di pasar SBN dipengaruhi oleh membaiknya kinerja ekonomi domestik yang tercermin dari rilis data makroekonomi seperti inflasi, cadangan devisa, serta didukung oleh tren kenaikan nilai tukar.

Investor non residen tercatat melakukan net beli. Investor non-residen tercatat melakukan net beli sebesar sebesar Rp22,58 triliun di pasar SBN pada April 2017, atau turun dibandingkan aliran dana masuk pada bulan sebelumnya yang mencapai Rp31,32 triliun. Penurunan ini dipengaruhi oleh meningkatnya tensi geopolitik sehingga investor cenderung berhati-hati (cautious). Investor juga cenderung melakukan aksi tunggu (wait and see) terhadap perkembangan kondisi global terutama terkait perkembangan Pemilu Perancis, pertemuan pimpinan Eurozone, perkembangan tax reform AS, maupun kondisi domestik seperti keputusan S\&P terkait dengan rating RI. Di samping itu, investor juga melakukan aksi ambil untung (profit taking) seiring tren penguatan SBN yang terus berlanjut. Dengan perkembangan tersebut, kepemilikan investor non residen di pasar SBN pada April 2017 tercatat naik menjadi 38,23\% dari sebelumnya 37,39\% (Grafik 47).

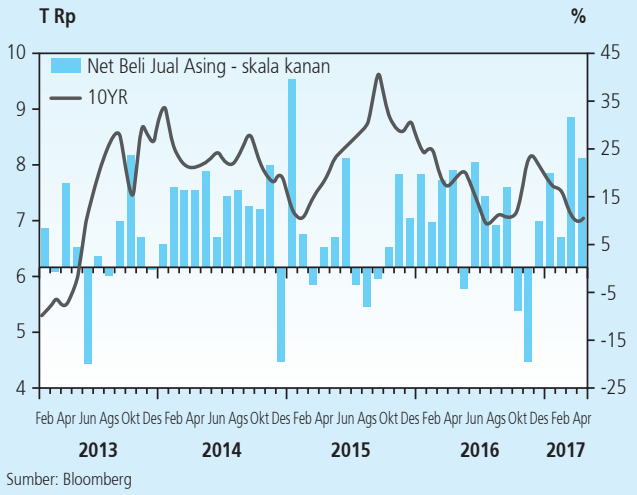

Grafik 46.

Yield SBN dan Net Jual/Beli Asing Triwulanan

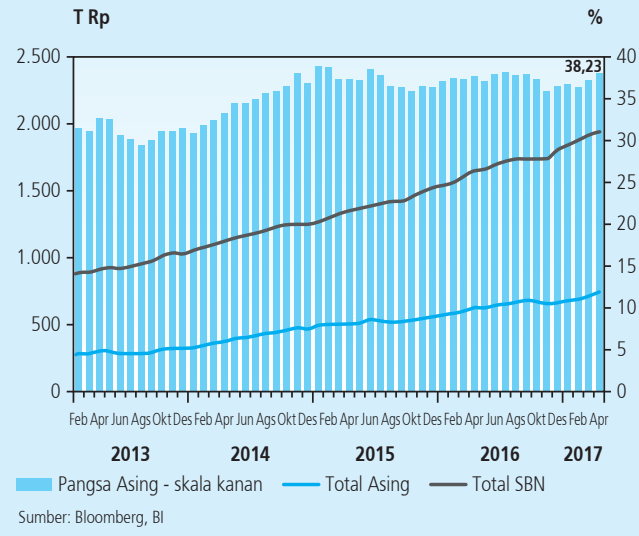

Grafik 47.

Perubahan Kepemilikan SBN Asing(mtm)

\subsection{Perkembangan Sistem Pembayaran}

Posisi Uang Kartal yang Diedarkan (UYD) menurun. Posisi UYD pada akhir triwulan I 2017 tercatat sebesar Rp562,7 triliun, turun sebesar Rp49,8 triliun atau 8,1\% (qtq) dibandingkan posisi akhir triwulan sebelumnya yang mencapai Rp612,5 triliun. Menurunnya posisi UYD tersebut seiring dengan arus balik uang dari masyarakat ke Bank Indonesia paska perayaan Hari Raya Natal dan Tahun Baru 2017 (seasonal factor). Secara tahunan, posisi UYD pada periode laporan tercatat Rp508,5 triliun atau tumbuh 10,7\% (yoy) (Grafik 48). Peningkatan UYD tersebut sejalan dengan perkembangan perekonomian nasional yang tetap tumbuh positif. 


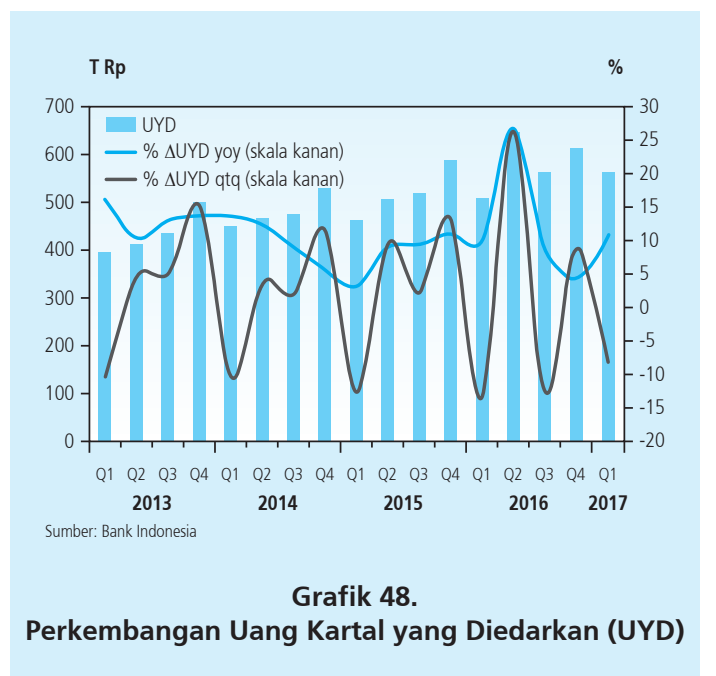

Untuk mendukung penyediaan uang kartal di seluruh wilayah NKRI, Bank Indonesia terus memperluas jaringan distribusi uang nasional melalui pembukaan kas titipan pada perbankan yang menjangkau wilayah-wilayah terpencil atau terluar. Bank Indonesia telah membangun roadmap coverage jaringan distribusi uang sekaligus coverage layanan kas yang dapat menjangkau seluruh wilayah NKRI. Selama triwulan I 2017, terdapat penambahan 6 (enam) kas titipan yaitu di Liwa (Provinsi Lampung), Baturaja (Provinsi Sumatera Selatan), Buntok (Provinsi Kalimantan Tengah), Sumbawa (Provinsi Nusa Tenggara Barat), Labuha (Provinsi Maluku Utara), dan Polewali Mandar (Provinsi Sulawesi Barat). Dengan perkembangan tersebut, sampai dengan akhir triwulan I 2017 terdapat total 68 wilayah kas titipan dengan jumlah peserta 560 kantor bank. Penambahan kas titipan tersebut berkontribusi pada tingginya penarikan uang kartal oleh bank pengelola kas titipan dari Bank Indonesia. Selama triwulan I 2017, terjadi penarikan sebesar Rp13,9 triliun, tumbuh lebih tinggi secara signifikan sebesar 97,5\% (yoy) dibandingkan triwulan yang sama tahun sebelumnya yaitu sebesar Rp7,1 triliun.

Secara umum, sistem pembayaran yang diselenggarakan oleh Bank Indonesia dan industri berjalan dengan aman, lancar, efisien dan handal. Nominal transaksi Sistem Pembayaran Non Tunai oleh Bank Indonesia (SPBI) pada triwulan I 2017 mencapai Rp44.169,10 triliun atau turun 7,40\% (qtq) dibanding triwulan sebelumnya yang tercatat sebesar Rp47.700,08 triliun. Penurunan nominal transaksi tersebut disebabkan oleh menurunnya nominal transaksi pada seluruh layanan SPBI (Tabel 5). 


\begin{tabular}{|c|c|c|c|c|c|c|c|c|c|c|}
\hline \multicolumn{11}{|c|}{$\begin{array}{c}\text { Tabel } 5 . \\
\text { Perkembangan Nilai Transaksi Sistem Pembayaran Non Tunai }\end{array}$} \\
\hline \multicolumn{11}{|c|}{ Volume (Ribu Transaksi) } \\
\hline \multirow{2}{*}{\begin{tabular}{c|} 
Transaksi Sistem \\
Pembayaran Nontunai
\end{tabular}} & \multicolumn{4}{|c|}{2016} & \multirow{2}{*}{$\begin{array}{l}\text { Total } \\
2016\end{array}$} & \multirow{2}{*}{2017} & \multicolumn{2}{|c|}{ Naik (turun) } & \multicolumn{2}{|c|}{$\%$ Naik (turun) } \\
\hline & Q-I & Q-II & Q-III & Q-IV & & & QtQ & YoY & QtQ & YoY \\
\hline BI-RTGS & $26.739,53$ & $27.117,76$ & $26.926,33$ & $31.043,73$ & $111.827,35$ & $28.924,76$ & $(2.118,98)$ & $2.185,22$ & $-6,83 \%$ & $8,17 \%$ \\
\hline - Pengelolaan Moneter & $11.960,33$ & $10.975,31$ & $11.008,30$ & $14.630,02$ & $48.573,96$ & $13.265,57$ & $(1.364,44)$ & $1.305,24$ & $-9,33 \%$ & $10,91 \%$ \\
\hline - Pemerintah & $1.159,52$ & $1.043,66$ & $1.257,81$ & $1.270,44$ & $4.731,43$ & $1.240,04$ & $(30,40)$ & 80,52 & $-2,39 \%$ & $6,94 \%$ \\
\hline - Masyarakat & $4.603,10$ & $5.232,32$ & $5.304,77$ & $5.991,29$ & $21.131,48$ & $5.464,49$ & $(526,79)$ & 861,39 & $-8,79 \%$ & $18,71 \%$ \\
\hline - Pasar Modal & $1.431,28$ & $1.623,57$ & $1.846,98$ & $1.693,98$ & $6.595,81$ & $1.643,13$ & $(50,85)$ & 211,85 & $-3,00 \%$ & $14,80 \%$ \\
\hline -Valas & $1.856,29$ & $2.098,90$ & $1.902,99$ & $1.840,63$ & $7.698,80$ & $1.887,00$ & 46,38 & 30,71 & $2,52 \%$ & $1,65 \%$ \\
\hline - PUAB & $1.584,27$ & $1.746,17$ & $1.609,17$ & $1.409,69$ & $6.349,29$ & $1.541,75$ & 132,06 & $(42,52)$ & $9,37 \%$ & $-2,68 \%$ \\
\hline - Lain-lain & $4.144,73$ & $4.397,85$ & $3.996,31$ & $4.207,70$ & $16.746,58$ & $3.882,76$ & $(324,93)$ & $(261,97)$ & $-7,72 \%$ & $-6,32 \%$ \\
\hline BI-SSSS & $12.994,90$ & $11.777,14$ & $12.082,03$ & $15.693,96$ & $52.548,02$ & $14.352,91$ & $(1.341,05)$ & $1.358,01$ & $-8,55 \%$ & $10,45 \%$ \\
\hline SKNBI & $1.110,34$ & $1.199,35$ & 891,98 & 962,39 & $4.164,07$ & 891,44 & $(70,95)$ & $(218,90)$ & $-7,37 \%$ & $-19,72 \%$ \\
\hline Debet & 371,00 & 372,81 & 340,12 & 359,48 & $1.443,41$ & 327,21 & $(32,27)$ & $(43,79)$ & $-8,98 \%$ & $-11,80 \%$ \\
\hline - Cek & 51,50 & 50,77 & 46,35 & 54,82 & 203,43 & 45,64 & $(9,17)$ & $(5,85)$ & $-16,73 \%$ & $-11,37 \%$ \\
\hline - Bilyet Giro & 319,41 & 321,94 & 293,68 & 304,57 & $1.239,61$ & 281,47 & $(23,10)$ & $(37,95)$ & $-7,59 \%$ & $-11,88 \%$ \\
\hline - Warkat Debet Lainnya & 0,09 & 0,10 & 0,09 & 0,09 & 0,37 & 0,10 & 0,00 & 0,01 & $2,49 \%$ & $12,49 \%$ \\
\hline Kredit & 739,35 & 826,54 & 551,86 & 602,91 & $2.720,66$ & 564,23 & $(38,68)$ & $(175,11)$ & $-6,42 \%$ & $-23,68 \%$ \\
\hline Total & $40.844,77$ & $40.094,25$ & $39.900,34$ & $47.700,08$ & $168.539,45$ & $44.169,10$ & $(3.530,98)$ & $3.324,33$ & $-7,40 \%$ & $8,14 \%$ \\
\hline
\end{tabular}

Transaksi melalui BI-RTGS selama triwulan I 2017 tercatat turun, baik secara nominal maupun volume. Di sisi nominal, transaksi melalui BI-RTGS pada triwulan I 2017 tercatat Rp28.924,76 triliun, turun 6,83\% (qtq) dibanding triwulan sebelumnya sebesar Rp31.043,73. Kondisi ini selaras dengan penurunan di sisi volume transaksi, yaitu turun sebesar $6,38 \%$ (qtq) (Tabel 6). Namun, secara tahunan, nominal dan volume transaksi melalui Sistem BI-RTGS pada triwulan I 2017 meningkat sebesar masing-masing 8,17\% (yoy) dan 67,27\% (yoy).

Transaksi BI-SSSS turun secara nominal. Nominal transaksi BI-SSSS pada triwulan I 2017 mencapai Rp14.352,91 triliun atau menurun 8,55\% (qtq) dibandingkan triwulan sebelumnya yaitu sebesar Rp15.693,96 triliun. Secara volume, transaksi BI-SSSS meningkat sebesar 1,38\% (qtq) dari 72,31 ribu transaksi menjadi 73,30 ribu transaksi. Secara tahunan, nominal dan volume transaksi meningkat sebesar masing-masing 10,45\% (yoy) dan 6,37\% (yoy).

Transaksi melalui SKNBI juga mengalami turun, baik secara nominal maupun volume. Nominal transaksi melalui SKNBI juga menurun yaitu sebesar 7,37\% (qtq), dari Rp962,39 triliun menjadi Rp891,44 triliun. Sejalan dengan penurunan nominal transaksi, volume transaksi juga tercatat menurun sebesar 5,76\% (qtq), yaitu dari 33.269,01 ribu transaksi menjadi 31.352,96 ribu transaksi. Adapun nominal transaksi kliring kredit pada periode laporan mengalami penurunan sebesar 6,42\% (qtq), yaitu dari periode sebelumnya sebesar Rp602,91 triliun menjadi sebesar Rp564,23 triliun. Secara tahunan, nominal transaksi melalui SKNBI pada triwulan I 2017 turun sebesar 19,72\% (yoy), sedangkan secara volume transaksi terjadi peningkatan sebesar 6,74\% (yoy). 


\begin{tabular}{|c|c|c|c|c|c|c|c|c|c|c|}
\hline \multicolumn{11}{|c|}{$\begin{array}{c}\text { Tabel } 6 . \\
\text { Perkembangan Volume Transaksi Sistem Pembayaran Non Tunai }\end{array}$} \\
\hline \multicolumn{11}{|c|}{ Volume (Ribu Transaksi) } \\
\hline \multirow{2}{*}{$\begin{array}{c}\text { Transaksi Sistem } \\
\text { Pembayaran Non Tunai }\end{array}$} & \multicolumn{4}{|c|}{2016} & \multirow{2}{*}{$\begin{array}{l}\text { Total } \\
2016\end{array}$} & \multirow{2}{*}{2017} & \multicolumn{2}{|c|}{ Naik (turun) } & \multicolumn{2}{|c|}{$\%$ Naik (turun) } \\
\hline & Q-I & Q-II & Q-III & Q-IV & & & QtQ & YoY & QtQ & YoY \\
\hline BI-RTGS & $1.436,25$ & $1.523,86$ & $2.131,25$ & $2.566,09$ & $7.657,45$ & $2.402,42$ & $(163,67)$ & 966,17 & $-6,38 \%$ & $67,27 \%$ \\
\hline - Pengelolaan Moneter & 26,93 & 28,19 & 27,40 & 32,88 & 115,40 & 33,88 & 1,00 & 6,95 & $3,04 \%$ & $25,79 \%$ \\
\hline - Pemerintah & 77,45 & 50,29 & 23,56 & 19,65 & 170,94 & 13,07 & $(6,58)$ & $(64,38)$ & $-33,48 \%$ & $-83,13 \%$ \\
\hline - Masyarakat & 979,47 & $1.050,57$ & $1.699,33$ & $2.085,10$ & $5.814,47$ & $1.946,49$ & $(138,61)$ & 967,02 & $-6,65 \%$ & $98,73 \%$ \\
\hline - Pasar Modal & 48,47 & 62,09 & 63,93 & 76,32 & 250,81 & 75,78 & $(0,53)$ & 27,31 & $-0,70 \%$ & $56,34 \%$ \\
\hline - Valas & 37,36 & 37,27 & 33,68 & 34,85 & 143,15 & 32,26 & $(2,59)$ & $(5,10)$ & $-7,42 \%$ & $-13,65 \%$ \\
\hline - PUAB & 20,52 & 22,10 & 20,21 & 18,52 & 81,34 & 19,57 & 1,05 & $(0,95)$ & $5,68 \%$ & $-4,64 \%$ \\
\hline - Lain-lain & 246,05 & 273,34 & 263,15 & 298,79 & $1.081,33$ & 281,37 & $(17,42)$ & 35,32 & $-5,83 \%$ & $14,35 \%$ \\
\hline BI-SSSS & 68,91 & 80,46 & 67,46 & 72,31 & 289,14 & 73,30 & 1,00 & 4,39 & $1,38 \%$ & $6,37 \%$ \\
\hline SKNBI & $29.372,08$ & $32.271,09$ & $29.617,04$ & $33.269,01$ & $124.529,22$ & $31.352,96$ & $(1.916,05)$ & $1.980,88$ & $-5,76 \%$ & $6,74 \%$ \\
\hline Debet & $8.664,63$ & $8.695,86$ & $7.728,27$ & $8.125,02$ & $33.213,78$ & $7.543,08$ & $(581,94)$ & $(1.121,55)$ & $-7,16 \%$ & $-12,94 \%$ \\
\hline - Cek & 759,68 & 763,60 & 687,54 & 731,60 & $2.942,42$ & 655,50 & $(76,10)$ & $(104,18)$ & $-10,40 \%$ & $-13,71 \%$ \\
\hline - Bilyet Giro & $7.785,64$ & $7.826,68$ & $6.950,83$ & $7.319,79$ & $29.882,94$ & $6.835,53$ & $(484,26)$ & $(950,10)$ & $-6,62 \%$ & $-12,20 \%$ \\
\hline - Warkat Debet Lainnya & 119,32 & 105,58 & 89,90 & 73,62 & 388,42 & 52,04 & $(21,58)$ & $(67,28)$ & $-29,31 \%$ & $-56,38 \%$ \\
\hline Kredit & $20.707,45$ & $23.575,23$ & $21.888,77$ & $25.143,99$ & $91.315,44$ & $23.809,88$ & $(1.334,11)$ & $3.102,43$ & $-5,31 \%$ & $14,98 \%$ \\
\hline Total & $30.877,25$ & $33.875,40$ & $31.815,75$ & $35.907,41$ & $132.475,80$ & $33.828,68$ & $(2.078,72)$ & $2.951,44$ & $-5,79 \%$ & $9,56 \%$ \\
\hline
\end{tabular}

Sistem pembayaran yang diselenggarakan oleh industri juga mengalami penurunan. Pada triwulan I 2017, nominal transaksi ritel masyarakat yang menggunakan instrumen Alat Pembayaran dengan Menggunakan Kartu (APMK) mengalami penurunan sebesar 4,10\% (qtq) menjadi Rp1,495 triliun. Dari sisi volume, transaksi juga menurun 3,74\% (qtq) menjadi 1.395, 5 juta transaksi. Namun, secara tahunan transaksi menggunakan APMK masih mengalami peningkatan, baik secara nominal maupun volume yakni masing-masing sebesar 9,25\% (yoy) dan 7,86\% (yoy). Pada jenis uang elektronik, nominal transaksi meningkat 7,86\% (qtq), sedangkan volume transaksi menurun $12,98 \%$ (qtq). Namun, secara tahunan nominal transaksi maupun volume transaksi uang elektronik masih meningkat, yaitu masing-masing sebesar $59.01 \%$ (yoy) dan $29.08 \%$ (yoy).

\section{PROSPEK PEREKONOMIAN}

Pertumbuhan ekonomi Indonesia pada tahun 2017 masih sesuai dengan prakiraan sebelumnya. Bank Indonesia memperkirakan pertumbuhan ekonomi pada tahun 2017 lebih tinggi dari tahun 2016 yaitu pada kisaran 5,0 - 5,4\%. Kinerja perekonomian domestik yang meningkat diperkirakan bersumber dari peningkatan investasi dan perbaikan ekspor. Investasi diperkirakan meningkat sejalan dengan berlanjutnya pembangunan infrastruktur dan mulai membaiknya investasi swasta nonbangunan. Sementara itu, perbaikan kinerja ekspor akan ditopang 
oleh kenaikan harga komoditas. Dari sisi lapangan usaha (LU), meningkatnya pertumbuhan ekonomi akan ditopang oleh membaiknya kinerja industri pengolahan, serta pengangkutan dan komunikasi sejalan dengan pemulihan ekonomi global dan perbaikan ekonomi domestik.

Dalam periode yang sama, inflasi diperkirakan tetap terkendali dalam kisaran sasarannya. Inflasi tahun 2017 diprakirakan lebih tinggi dibandingkan tahun sebelumnya namun tetap terkendali dalam kisaran targetnya sebesar 4 土 1\%. Tekanan inflasi 2017 diperkirakan bersumber dari beberapa kebijakan terkait administered prices seperti terkait tarif tenaga listrik, harga BBM non subsidi (selain premium dan solar), dan biaya perpanjangan STNK. Sementara itu, tekanan inflasi inti tahun 2017 diprakirakan moderat dan tekanan inflasi volatile food diperkirakan terkendali.

Bank Indonesia akan terus mencermati beberapa risiko yang membayangi perekonomian Indonesia ke depan. Dari sisi global, risiko tersebut antara lain berkaitan dengan dampak dari kenaikan Fed Fund Rate, kebijakan fiskal dan perdagangan serta penurunan besaran neraca bank sentral AS, dan perkembangan geopolitik di beberapa kawasan, khususnya di Semenanjung Korea. Dari sisi domestik, beberapa risiko yang tetap perlu diwaspadai adalah terkait dampak penyesuaian administered prices terhadap inflasi, serta berlanjutnya konsolidasi korporasi dan perbankan. Untuk memitigasi berbagai risiko tersebut, Bank Indonesia terus memperkuat bauran kebijakan moneter, makroprudensial, dan sistem pembayaran guna menjaga stabilitas makroekonomi dan sistem keuangan. Bank Indonesia juga terus mempererat koordinasi bersama Pemerintah dalam rangka pengendalian inflasi agar tetap berada pada kisaran sasaran dan mendorong kelanjutan reformasi struktural agar dapat mendukung pertumbuhan ekonomi yang berkesinambungan. 
384 Buletin Ekonomi Moneter dan Perbankan, Volume 19, Nomor 4, April 2017

Halaman ini sengaja dikosongkan 